IFN Working Paper No. 1245, 2018

\title{
The Rise of Private Foundations as Owners of Swedish Industry: The Role of Tax Incentives 1862-2018
}

Dan Johansson, Mikael Stenkula and Niklas Wykman 


\title{
The Rise of Private Foundations as Owners of Swedish Industry: The Role of Tax Incentives 1862-2018*
}

\author{
Dan Johansson $^{\mathrm{a}}$, Mikael Stenkula ${ }^{\mathrm{b}}$, and Niklas Wykman ${ }^{\mathrm{c}}$
}

\begin{abstract}
The tax system has at times favoured firm control through private foundations, which has been argued to inhibit high-impact entrepreneurship and economic growth. However, research has been hampered due to a lack of systematic historical tax data. The purpose of this study is threefold. First, we describe the evolution of tax rules for private foundations in Sweden between 1862 and 2018. Second, we calculate the marginal effective tax rate on capital income. Third, we examine the incentives to use private foundations as a means for corporate control by comparing the taxation of private foundations and of high-impact entrepreneurs. Tax incentives help explain why economically significant private foundations were founded between World War I and the 1960s.
\end{abstract}

Keywords: family firms; foundations; high-impact entrepreneurship; owner; taxation JEL codes: D31; H32; K34; L26; N23; O43; P12; P14

\footnotetext{
* We are grateful for comments from Niclas Berggren, Magnus Henrekson, Johan Karlsson, Peter Meltz and participants at the 87th Annual SEA conference in Tampa, Florida, and at Örebro University. Stenkula gratefully acknowledges financial support from the Jan Wallander and Tom Hedelius Foundation and the Marianne and Marcus Wallenberg Foundation. a Örebro University School of Business and HUI Research, SE - 70182 Örebro, Sweden. Email: dan.johansson@oru.se.

${ }^{\mathrm{b}}$ Research Institute of Industrial Economics (IFN), P.O. Box 55665, SE - 10215 Stockholm, Sweden. E-mail: mikael.stenkula@ifn.se. Corresponding author.

c Örebro University School of Business, SE - 70182 Örebro, Sweden. E-mail: niklas.wykman@oru.se
} 


\section{Introduction}

Private foundations have been an important means for a few influential family groups to exercise far-reaching control over Swedish industry, possibly because they have been tax-exempt. This has provided an advantage over firms controlled by personal ownership. It has been argued that this has hampered entrepreneurship and consequently economic growth (Henrekson, 2005; Henrekson \& Jakobsson, 2001; Henrekson \& Johansson, 1999). However, there are no time series on the taxation of private foundations, and it has therefore been impossible to estimate to what extent they have been favoured. Hence, there is a need to produce long homogeneous time series on their taxation to further our understanding of the governance and development of Swedish industry.

As will be described later in more detail, Swedish foundations with charitable purposes (Swedish: allmännyttiga stiftelser) are exempted from tax on capital income, wealth, inheritance and gifts. Nevertheless, their real after-tax return on investments in firms depends on corporate income taxation, inflation (because Sweden applies a nominal-based tax system) and source of finance (because different sources of finance are treated differently by tax law). They may also pay other taxes, e.g., property taxes or taxes on business activity. Previous research, e.g., King and Fullerton (1984), Södersten (1984, 1993) and Henrekson and Jakobsson (2001), has denoted these foundations 'taxexempt foundations.' In the US, the term 'private foundation' is used for tax-exempt foundations with charitable purposes established by individuals or families, and we will conform to this connotation throughout the paper.

The purpose of this study is, first, to describe the evolution of tax rules for private foundations. Second, we calculate the marginal effective tax rate (METR) on capital income for private foundations. Third, we examine the incentives to use private 
foundations as a means of control by comparing the taxation of private foundations and high-impact entrepreneurs. ${ }^{1}$ The analysis covers the years 1862 to 2018.

The METR is an established tax measure used to compare tax rates between countries and investment projects (e.g., Johansson et al., 2015; Johansson et al., 2018; Öberg, 2003; Södersten, 1984, 1993 and Wykman, 2018). It analyses the effect of capital taxation on a marginal investment accounting for the total effect of the taxation of owners; i.e., it includes the effects from corporate income taxation, capital income taxation and wealth taxation, and the interactions of these taxes with inflation.

The analysis complements earlier studies on the evolution of the taxation of households (Johansson et al., 2015) and owners of closely held corporations (Johansson et al., 2018). It is part of a comprehensive project to characterize the Swedish tax system from 1862, when Sweden introduced a new tax system, up until the present. $^{2}$ Henrekson and Stenkula (2015) and Stenkula (2014) summarize the results.

Our analysis helps explain why the economically significant private foundations were established between World War I and the 1960s. Tax incentives for exercising control through private foundations were negligible until World War I. Increased taxes after World War I, especially after World War II, made it most difficult to retain and transfer the ownership of large family firms to the next generation. Starting in 1991, tax reforms made the tax system more neutral. In fact, personal ownership is cash flow favoured; i.e., owners who hold stocks personally can keep a larger share of the cash

\footnotetext{
${ }^{1}$ As will be shown, the private foundations controlling a significant share of Swedish industry were founded by high-impact entrepreneurs or their descendants. We will use the term highimpact entrepreneurs for entrepreneurs who successfully commercialize key innovations, which may generate extra ordinary income and wealth. However, 'entrepreneurial income and wealth' is not recognized in the tax code, and we will approximate the taxation of high-impact entrepreneurs with an owner of a listed firm facing the highest marginal tax.

${ }^{2}$ Seven key aspects have been treated in previous studies: the taxation of capital income of households, consumption, gifts and inheritance, labour income, real estate, wealth, and taxation of the owners of closely held firms (See Henrekson \& Stenkula, 2015; Johansson et al., 2018; Wykman, 2018).
} 
flow generated in the company because private foundations have to distribute the bulk of their capital income (excluding capital gains) to charitable purposes.

The rest of the paper is organized as follows. Section 2 discusses the use of private foundations as a means for the family control of firms. Section 3 describes the taxation of private foundations between 1862 and 2018. Section 4 introduces the King and Fullerton framework and calculates the METR for private foundations. Section 5 examines tax incentives for high-impact entrepreneurs to exercise the control of firms through private foundations by comparing the taxation of high-impact entrepreneurs and private foundations. Section 6 concludes the paper. Appendix A presents the marginal tax rates used and the calculated METR for the whole period.

\section{Private foundations and family control}

Foundations in Sweden date back to the Christianization of Sweden, when people made donations to the church, for instance, for poor relief. Since the $18^{\text {th }}$ century, foundations have been used to support education and care for the poor. Higher education and scientific research became more important for foundations in the late $19^{\text {th }}$ century (SOU 1995:63). However, foundations were separately regulated by law first in 1929 through the so-called Supervision Act (Tillsynslagen). In 1996, foundations received an unambiguous legal definition in the Foundation Act (Stiftelselagen) (Gunne \& Löfgren, 2014). One does, however, need to distinguish between the civil and tax legislations. The Foundation Act (SFS No. 1994:1220) defines the foundations in civil law, but the tax legislation is separate and described in section 3

Foundations are heterogeneous, but they share some common traits. First, a foundation is founded when property is permanently separated and dedicated to the 
promotion of a particular purpose (Stenshamn, 1967). Second, foundations are selfowned (i.e., lack owners) and governed by their statutes (Gunne \& Löfgren, 2014).

Foundations can be sorted into different categories depending on what features are of interest. One distinction is between dependent and independent, i.e., whether a foundation is controlled within a structure, such as a nonprofit organization or a company, or whether its board is independent and controls itself (Stenshamn, 1967).

Another sorting method is to divide foundations into return foundations (avkastningsstiftelser) and business foundations (näringsdrivande stiftelser), where the former meets its purpose by funding different activities, primarily by the return on its capital, and the latter by conducting business. Foundations that conduct business are rare, however, since a foundation does not offer the same flexibility as a limited company (Gunne \& Löfgren, 2014).

A third sorting method is by purpose, and the foundations are then normally divided into the following categories (SOU 2009:65):

1. ordinary foundations (vanliga stiftelser);

2. collection foundations (insamlingsstiftelser);

3. collective agreement foundations (kollektivavtalsstiftelser); or

4. pension and personnel foundations (pensions- and personalstiftelser).

Ordinary foundations are a broad category and include foundations with a wide variety of purposes, e.g., local charity work and scholarships, family foundations ${ }^{3}$ and the Nobel Foundation. A condition for being classified as an ordinary foundation is that the founder(s) of the foundation transfer(s) assets to the foundation for a particular

\footnotetext{
${ }^{3}$ Family foundations hold funded assets with the purpose of promoting a particular family's prosperity.
} 
purpose. These assets are not allowed to be distributed; it is only the return on the assets that can be distributed.

The collection foundations are similar to the ordinary foundations. The difference is that the founder(s) do(es) not transfer any wealth when founding the foundation. Instead, a collection foundation raises money to meet its objectives. The funds are normally meant to be spent for the predetermined purpose, even though some funds might be saved, and there are hybrids between collection funds and those who only use their return to finance their purpose. From a tax perspective, this distinction lacks relevance (Gunne \& Löfgren, 2014).

Collective agreement foundations have a more precise purpose: to support the transformation of the labour market. This can be done in a number of ways, such as education, financial support for accepting lower paid jobs and early retirement. These foundations are funded by the employers as a part of the collective agreement and controlled by the trade unions and employers' organizations.

Pension and personnel foundations are used to guarantee employers' pension assurances and personnel benefits to employees.

For the purpose of this paper, the most relevant property of the foundations is their tax condition. In general, ordinary foundations have to pay tax on all income; i.e., they are fully taxable (SOU 2009:65). The collection foundation has the same tax conditions as the ordinary foundation. Collective agreement foundations belong to a small number of foundations that are exempted from tax on all incomes, including business activity income. These foundations are taxed only for property. Pension foundations are fully taxed for property, and their return is taxed with 15 percent on the net assets multiplied by the government borrowing rate (statslåneräntan) (Gunne \& Löfgren, 2014, p. 76). Personnel foundations normally have full tax liability (oinskränkt 
skattskyldighet). Provisions to personnel foundations are tax deductible at the firm level, and payments from the foundation to the personnel are taxed at an individual level (Gunne \& Löfgren, 2014).

However, foundations that promote charitable purposes are exempted from tax on capital income, wealth, inheritance and gifts. ${ }^{4}$ To be exempted from tax on capital income, there are certain rules that have to be met (as explained in more detail in section 3). ${ }^{5}$ This possibility provides an opportunity for entrepreneurs to keep firms under family control over generations in spite of taxation. ${ }^{6}$ By establishing a private foundation, i.e., an ordinary foundation with the purpose of promoting charitable purposes, the foundation has limited tax liability and the assets are not allowed to be distributed. ${ }^{7}$

In addition to tax incentives and the willingness to promote charitable purposes, another motive for establishing private foundations can be to avoid inheritance division. By bequeath to a foundation, the founder avoids dividing the assets among several heirs, making it easier to maintain a critical level of capital within one voting structure. Heirs

\footnotetext{
${ }^{4}$ There is also a category of foundations that do not have to be charitable to achieve the same tax advantages described below. Such foundations have been listed separately in the law since 1855. The first such foundation is Jernkontoret, supporting the iron industry (SOU 2009:65). Even though the catalog has grown over time, it does not include foundations able to functions as a substitute for private ownership; instead, it consists of foundations such as the Nobel Foundation and foundations in memory of persons.

${ }^{5}$ Family foundations are taxed as a natural person (Stenshamn, 1967) because their purpose is to favour a particular family, and they cannot be philanthropic by definition.

${ }^{6}$ Because the wealth is meant to be distributed, collection foundations are not used as an instrument to exercise control over firms.

${ }^{7}$ Ordinary foundations with the purpose to promote charitable purposes share commonalities with private foundations in the USA; they are independent legal entities set up for solely charitable purposes; the funding typically comes from a single individual or a family; the founder determines the foundation's mission, whom to include on the board, investment strategy, and how and where funds are given away; the foundations are governed by their own board of directors, which consists of the founder(s), family and/or other individuals chosen by the founder(s); they must make charitable distributions and are classified as tax-exempt, but they still may have to pay some taxes. However, donors are not provided with a tax deduction in Sweden.
} 
are further prohibited from wasting the inheritance, and the family may also gain social status.

\subsection{Ownership spheres and private foundations ${ }^{8}$}

There are no information or time series of foundations' total assets because this information has not been collected and reported to a central register. Foundations have, however, been important devices for ownership spheres to exercise control over Swedish industry. In combination with differentiated voting rights and so-called 'pyramid-building', several companies could be controlled with a relatively small amount of capital (Hagstedt, 1972). These spheres are few and well known and have a large influence on the Swedish economy, which makes them possible to identify. Because of their economic significance, they have received attention from policy makers and analysts who have investigated their assets and influence (e.g., Dagens Industri, 2017; Hermansson, 1959, 1971; Sundqvist, 1985-2015). There are also a number of bibliographies describing the entrepreneurs and their family groups (e.g., de Geer, 1998; Edvinsson, 2005; Feldt, 2012; Glete, 1994; Lindgren, 2007; Nilsson, 1984, 1989, 1994; Olsson, 2006; Sjögren, 2017).

In the early 1960s, 17 ownership spheres controlled one-third of the largest firms' capital, and one-fifth of total private employment was employed in firms controlled by these ownership spheres (excluding bank and insurance companies). Fourteen of these spheres were controlled by family groups. ${ }^{9}$ Of the other three, two were controlled by managers (who did not hold any controlling shares), and one did not have controlling ambitions (SOU 1968:7). ${ }^{10}$

\footnotetext{
${ }^{8}$ A more detailed description is provided in Appendix B.

${ }^{9}$ See Andersson et al. (2018) for the importance of family firms in Sweden.

${ }^{10}$ This refers to the so-called 'Dunker sphere', which was controlled by Helsingsborg's city council and independent persons.
} 
Foundations have been used as the main controlling device in approximately half of the ownership spheres (eight of 17). Foundations have, in particular, been used to build and maintain a strong influence in the Swedish industry by a small group of high-impact entrepreneurs and their families. ${ }^{11}$ The wealth donated to the private foundations mainly consisted of shares in the family firm(s), which originated from entrepreneurs who were active during the Swedish industrialization in the latter half of the $19^{\text {th }}$ century.

In 2018, there were approximately 17,000 foundations in Sweden ${ }^{12}$ (County Administrative Board, Länsstyrelsen). It has been estimated that approximately 90 percent of all registered foundations are tax-exempt (SOU 2009:65). The vast majority of all foundations are also small. Nevertheless, a few foundations control a large share of Swedish industry. Interestingly, the largest foundations are the same as those identified in the early 1960s. The foundations controlled by the Wallenberg and the Ax:son Johnson families stand out. There are also some new emerging family groups that have created substantial wealth, e.g., Fredrik Lundberg's, Gustaf Douglas', Melker Schörling's, Sten A. Olsson's and Stefan Persson's family groups. Notably, these family groups do not rely on foundations as a device for control but control their groups by personal ownership of their wholly owned holding companies. ${ }^{13}$

A closer analysis of the founding of the foundations reveals that most of the foundations used to control Swedish industry were established in the post-war era (see

\footnotetext{
${ }^{11}$ The ownership spheres controlled by foundations were the Ax:son Johnson family, the Dunker sphere, the Ericsson family, the Kempe family, the Söderberg family, the Wallenberg family and the Åhlén family. The spheres that were not controlled by foundations (or where the foundations were of less importance for control) were Bergengren, Bonnier, Broström Custos/Säfveån-Skandinaviska Banken, Edstrand, Klingspor-Stenbeck, Kockum, Mark and Carlander and Wehtje.

${ }^{12}$ And an additional small number for personnel, pension and collective agreements foundations.

${ }^{13}$ The new family groups have also established foundations, but these foundations are too small to be primarily used for control.
} 
Appendix B for a detailed description). ${ }^{14}$ The exceptions are Knut och Alice

Wallenbergs Stiftelse founded in 1917 and Stiftelsen J.C. Kempes Minne (1936) and

Stiftelsen Seth M. Kempes Minne (1941). Knut and Alice Wallenberg had no children, and Knut was 64 years old in 1917. Stiftelsen J.C. Kempes Minne and Stiftelsen Seth M. Kempes Minne was founded by Charlotte 'Lotty' Bruzelius (1855-1941) in memory of her father J.C. Kempe and her brother, Seth Kempe. She died childless.

\section{Taxation of private foundations}

The calculation of the METR requires data on the evolution of the corporate income tax, the foundation's income tax, the wealth tax and the inflation rate. Section 3.1 describes how the tax rules for private foundations have evolved and how a foundation's income has been taxed over time. Section 3.2 presents the evolution of the corporate income tax, and section 3.3 depicts the inflation rate. As private foundations do not pay wealth taxes, we do not describe the evolution of this tax. We refer to Henrekson and Stenkula (2015), Johansson et al. (2015) and Stenkula et al. (2014) for a more thorough presentation of the tax system.

\subsection{Tax rules for private foundations}

Private foundations do not have to pay tax on capital income, such as dividends, interest and capital gains and tax on wealth, inheritance and gifts. However, they have to pay

\footnotetext{
${ }^{14}$ Founding year in parentheses: Axel och Margaret Ax: son Johnsons Stiftelse för allmännyttiga ändamål (1947), Axel och Margaret Ax:son Johnsons Stiftelse (1947), Henry och Gerda Dunkers Stiftelse (1953), Åhléns-stiftelsen (1954), Ollie och Elof Ericssons Stiftelse för Vetenskaplig Forskning (1958), Stiftelsen Marcus och Amalia Wallenbergs Minnesfond (1960), Torsten Söderbergs Stiftelse (1960), Ragnar Söderbergs Stiftelse (1960), Ollie och Elof Ericssons Stiftelse för Välgörande Ändamål (1961), Stiftelsen Henry och Gerdas Donationsfond Nr 1 (1962), Stiftelsen Henry och Gerdas Donationsfond Nr 2 (1962) and Marianne och Marcus Wallenbergs Stiftelse (1963). Interestingly, the founding wealth in these foundations emanates from high-impact entrepreneurship during the Swedish industrialization during the second half of the mid-19th century.
} 
taxes on income from property and from business activities undertaken by the foundation itself. These rules have evolved through time in a combination of changing statutory laws and case laws.

The roots of tax rules for foundations go back to regulation from 1810, where so-called pious foundations (fromma stiftelser) were exempted from tax. Already in 1810, the tax law stated that foundations were exempted from paying tax on chattels, immovables, gifts and inheritance (Stenshamn, 1967). In the new Appropriation law (Bevillningsförordning) introduced in 1862, the tax exemption was widened to several areas of research, education, childcare and healthcare.

The main idea behind a pious foundation was that the expenses of such foundations should only be made for charitable purposes. One rationale for the tax exemption was that these foundations spent money on activities that otherwise had to be financed by taxes directly through the political system. A foundation could, however, have more than one purpose (and as a consequence use its revenues in more than one way). If only part of the foundation had charitable purposes, then these rules applied only for that part. If, for example, half of the foundation's activity had charitable purposes (as stated, e.g., in the statutes of the foundation), half of the income must be spent on charitable purposes, and this half was exempted from income taxation. A foundation with multiple purposes could in this way keep some money within the foundation without being required to use all spent income on charitable purposes (but as a result, such foundations were not completely exempted from income taxation). Hence, the degree of tax-exempt income was dependent on the share of income used to support the charitable purposes. ${ }^{15}$

\footnotetext{
${ }^{15}$ See SOU 1939:47 and SOU 2009:65 for a more detailed discussion.
} 
In 1942, the legal framework was formalized, and the foundation of the current legal framework came in place. The legislation was preceded by a long process based on a proposal from a tax committee of 1936 . The rules have since been basically the same. Before 1942, the main focus of the tax authorities was whether a foundation could be regarded as a pious foundation. Classification as a pious foundation was based on case law, but the case laws were not consistent because regional courts could make different interpretations of whether a foundation fulfilled the requirement to be tax exempted.

One main concern with the rudimentary statutory law before 1942 was that it in practice was possible to store and accumulate the yearly income that the foundation received on the grounds that, in the future, the money must be spent on charitable activities. However, the purpose of the foundation could be changed or the foundation could be dissolved and liquidated. There was, hence, a risk that tax-exempted income could be used for non-charitable activities (if the purpose of the foundation was changed) or could be obtained by ordinary people (if the foundation was liquidated). ${ }^{16}$

With the new law, the legislation clarified that foundations supporting philanthropy should be taxable only for income from property and business activity. ${ }^{17}$ However, three metrics had now to be formally fulfilled for other incomes of a foundation to be tax-exempted:

- The purpose requirement (ändamålskravet), stating that the foundation must have (a) charitable purpose(s). A list of charitable purposes was specified in the

\footnotetext{
${ }^{16}$ There is a limited possibility to go back in time and change the taxation of income. Current tax law allows the tax authority to change the taxation of income at most five years back in time (eftertaxering).

${ }^{17}$ At this time, the property tax had two parts, local and national, and these foundations had to pay only the local part. It was argued that removing the local part would reduce the municipal financing in a non-legitimate manner.
} 
law (SOU 2009:65). The list of charitable purposes replaced the concept of pious in the law. ${ }^{18}$

- The activity requirement (verksamhetskravet), stating that the aim of the foundation must be to mainly (huvudsakligen) promote charitable purposes. In practice, this means that 90 to 95 percent of the resources used must promote these charitable purposes.

- The completion requirement (fullföljdskravet), stating that the foundation's return to a reasonable extent (skälig omfattning) should be used to promote the purpose. 'Reasonable' has, according to case law, been defined as 80 percent of the net return (as described in the next section, it is not 80 percent of the total return that has to promote the purpose). Normally, this requirement could be fulfilled either in the current fiscal year or by summarizing the last four years and the year to come (Gunne \& Löfgren, 2014).

With a formal completion requirement, it would not be possible to accumulate (all or the bulk of) tax-exempted income in the foundation over time (on the grounds that it will be spent on charity sometime in a distant future). With the activity requirement, the foundation was, on the other hand, not obliged to use everything it spent (but only the main part) on charitable activities. This was seen as a well-balanced trade-off between different problems with the earlier statutory tax law.

The rules were now also made binary, meaning that either the criteria to be taxexempted were fulfilled-and then all income (with the exception of income from property and business income) was tax exempt—or the criteria were not met-and then all income had to be taxed (as if earned in a company). Hence, foundations could no

\footnotetext{
${ }^{18}$ With the 1942 legislation, the definition of research was broadened but the change in practice was negligible since the interpretation was already generous (Stenshamn, 1967).
} 
longer divide their income into non-taxable (the charitable part) and taxable (the noncharitable part) income. A foundation can either fulfil all the requirements and be tax exempted from most taxes, or it can fail to satisfy (at least) one of the requirements and then be fully taxable. Such rules can have far-reaching consequences in situation where the criteria are not met. An alternative tax rule, which would keep the tax incentives for foundations with charitable purposes in place, could be to allow foundations to deduct all expenditures with charitable purposes and then tax the residual net income in the same way as other businesses. This has been rejected for two main reasons: high administrative burden for the foundation and weakened opportunities for consolidation since new investments would have to be carried out with post-tax incomes (SOU 1995:63). It should be noted that decreased income tax has made the latter argument less valid.

In practice, the new rules implied that, on average, approximately 80 percent of the net return had to be spent every year, and of these expenditures, 90 to 95 percent must be on activities that the tax authority regards as charitable.

There have been some changes since 1942, but basically the idea behind the rules has remained the same. In 1964, the definition of charitable purposes was widened with Nordic cooperation, and in 1984, the municipality taxation of legal entities was abolished. It should be noted that no changes in the taxation of foundations were made during the major Swedish tax reform in 1990-1991. In 1999, the activity requirement was changed from mainly (huvudsakligen) to solely or virtually solely (uteslutande eller så gott som uteslutande). The tax laws for foundations were made more liberal in 2014, 
but these changes did not essentially change the possibility to own or control firms via foundations (Gunne \& Löfgren, 2014). ${ }^{19}$

Importantly, no exact numbers are mentioned directly in the law. Both case laws and circumstances are relevant for the exact determination of how much of the return must be used for charitable purposes to exempt a foundation from most taxes instead of considering it a fully taxed foundation during the whole period.

\subsubsection{The completion requirement and the requirement base}

As described in the section above, approximately 80 percent of the net return has to be spent on charitable purposes to fulfil the completion requirement. However, the requirement base out of which 80 percent has to be donated does not exactly correspond to the total return from the foundation as described in this section.

The requirement base includes current income in the form of all revenues from interest and dividends. Capital gains are excluded. ${ }^{20}$ Income from business activity and property is likewise not included because these incomes are not tax exempted for private foundations (Gunne \& Löfgren, 2014). Furthermore, the taxes that the foundation pays are also deducted from the income.

Income from donations and bequests must be included if it is stated in the will that it must be used to promote the charitable purposes of the foundation. However, without this explicit statement in the will, bequests and other gifts are normally not included in the requirement base (Hagstedt, 1972).

\footnotetext{
${ }^{19}$ Changes include that the legislature now specified philanthropic purposes as sports, culture, environmental care, care for children and adolescents, political activity, religious activity, health care, social ancillary, Sweden's defence and collaboration between agencies, education, scientific research and other equivalent activities (Gunne \& Löfgren, 2014).

${ }^{20}$ For certain financial instruments it is difficult to distinguish between current income and capital gains. For some instruments there are well defined rules, but for other instruments one must use a case-by-case methodology.
} 
Finally, direct and indirect costs associated with earning the income (kostnader för intäkternas förvärvande), such as board fees, administration and asset management, are deductible. The general rule is that costs that would be tax deductible in a situation where the income is taxable are deductible from the gross income when calculating the requirement base (Swedish Tax Agency, 2018).

The requirement base can be expressed as:

Requirment base $=$ Total income - Income from business activity Income from property - Income from capital gains - Gifts and bequests Taxes - Costs associated with earning the tax exempt income

Although it is not clearly stated in the law, costs associated with fulfilling the completion requirement (fullföljdskostnader), such as costs for distributing information about scholarships or costs for evaluating scholarship applications, are normally included in the 80 percent so that 20 percent can always be reinvested (Government bill 2013/2014:1).

For the purpose of this paper, the most important thing to note with Equation (1) is that revenues from dividends and interest are included in the requirement base, but capital gains are not. Since dividends and capital gains are not treated equally, it is possible to influence how much of the total return the foundation has to use to promote its purpose by the choice of remuneration. ${ }^{21}$

\subsubsection{Summary and conclusion concerning foundations}

In modern times, it has always been possible to use foundations to avoid personal

\footnotetext{
${ }^{21}$ This is possible if the foundation has enough influence to decide the dividends strategy for the firm. This condition provides incentives for the foundation to control large enough voting rights to have such influence. However, selling shares comes at the cost of losing control and therefore has generally been avoided.
} 
income, wealth and inheritance tax. ${ }^{22}$ Although there have been discussions about extending the tax liability, the development has been the opposite. In essence, the regulatory changes for the private foundations have mainly entailed the transformation of case law into statutory law. However, there have been several court cases that have assessed the boundaries for the possibility to be a private foundation.

However, the tax limitation comes with three major disadvantages from the owner perspective. First, to control a company via a foundation, one must relinquish the ownership of the capital, and second, the bulk of income must be used for purposes determined by the legislature (as described in section 3.1). Finally, there is a lock-in effect; entrepreneurs can emigrate, while foundations cannot. When taxation on entrepreneurs is eased, the relative cost of controlling firms through private foundations increases.

\subsection{Corporate income taxation}

Investments made by corporations controlled by private foundations are due to corporate income tax. Figure 1 depicts the evolution of the marginal corporate income tax rate from 1862-2018. Corporate taxes were paid to the state (central government) and, until 1985, also to the municipalities (local government). The tax was progressive between 1903 and 1939, and the figure shows the highest and lowest statutory tax rates during this time.

\footnotetext{
${ }^{22}$ Fully taxable foundations also have had tax benefits in comparison with personal/individual ownership. The marginal inheritance tax rate for natural persons has been as high as 60 percent, while at the same time, it has been 30 percent for taxable foundations (Stenshamn, 1967), and as long as the tax rate for wealth tax was progressive, foundations were favored since their tax rate was flat (Gunne \& Löfgren, 2014).
} 
Figure 1. The highest and lowest statutory marginal corporate income tax rate, 18622018.

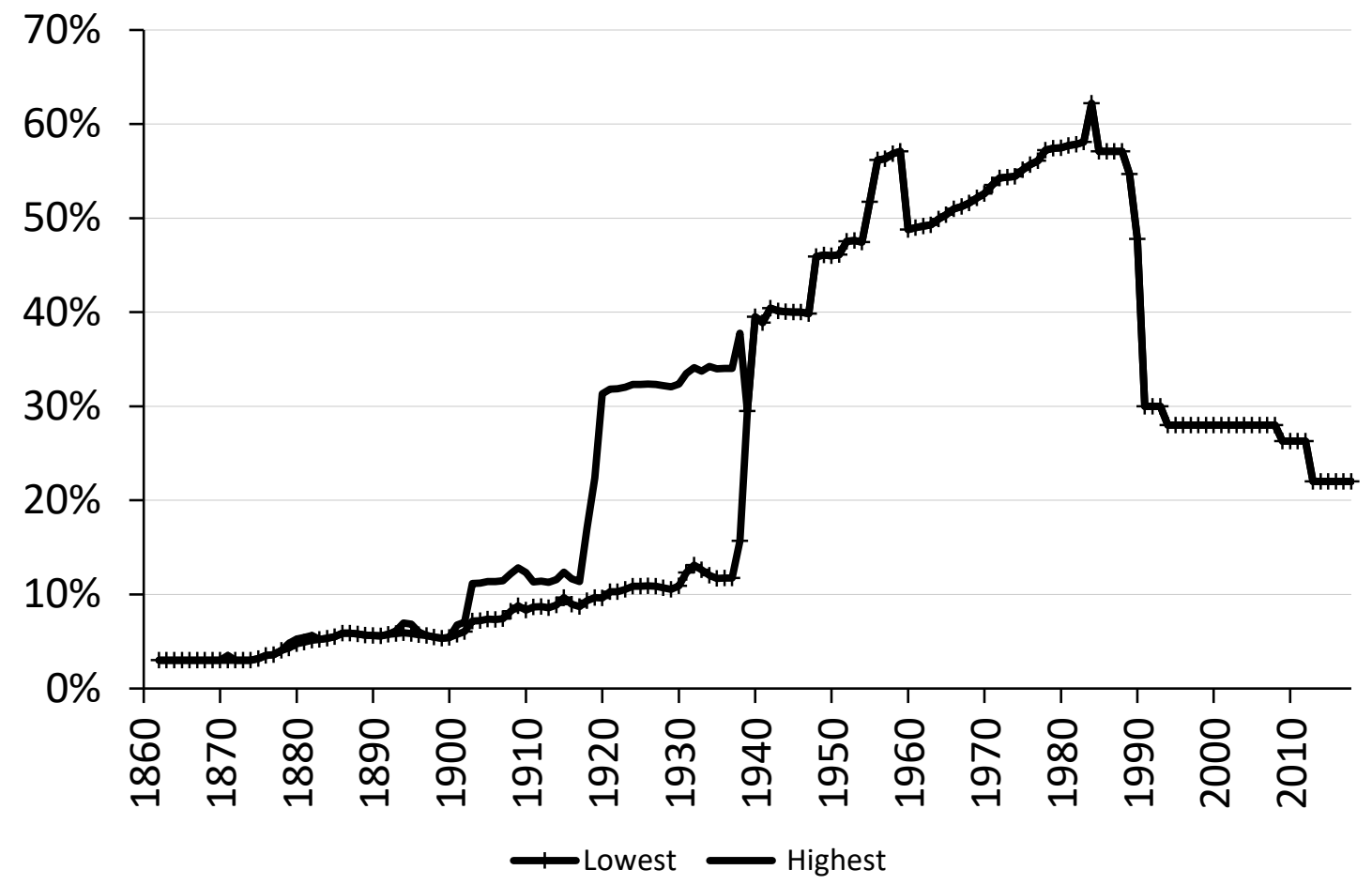

Note: The statutory marginal corporate income tax rate refers to the total effect of local and state corporate income taxes. The progressive state corporate income tax was replaced by a proportional tax in 1939 .

Source: Johansson et al. (2015) and updating.

In the first 60 years of our study, the tax rates were low (below 15 percent) compared to later tax rates. The highest marginal tax rate increased sharply after World War I. The lowest marginal tax rate increased sharply in 1939 when the system was made proportional. The statutory tax rates continued to increase during the post-war period and exceeded 50 percent in the mid-1950s. The 1990-1991 tax reform sharply decreased the statutory tax rate to 30 percent. The tax rate continued to decrease to 22 percent in 2013. Between 1984 and 1990, an additional, specific 'profit sharing tax' 
(PST) on corporations was also levied to finance so-called wage-earner funds

(löntagarfonder). ${ }^{23}$

There have been ample opportunities to reduce the statutory corporate tax by allowances and grants—particularly between 1939 and 1991, when the effective corporate tax rate could be substantially lower than the statutory corporate tax rate. The tax reform in 1990-1991 aimed at weakening these options. ${ }^{24}$

\subsection{Inflation}

The inflation rate varied, with few exceptions, between -5 and +5 percent until World War I, but it was zero on average, and the price level was virtually stable (see Figure 2). Inflation peaked during World War I and was close to 50 percent in 1918. Deflation followed the war with a policy to restore the price level to the pre-war level, and deflation was nearly 20 percent in 1921. Sweden also experienced deflation at the end of the 1920s and at the beginning of the 1930s. On average, the price level was roughly stable for approximately 80 years between 1862 and 1939. Inflation peaked again during World War II and during the Korea boom in the 1950s. In addition, inflation was moderate during the 1950s and 1960s and rarely exceeded five percent. It increased during the 1970s and 1980s and occasionally exceeded 10 percent. The central bank was granted independence, price stability was made prime goal of monetary policy and an inflation target to keep inflation at approximately two percent was established in the

\footnotetext{
${ }^{23}$ It has been estimated that this tax increased the statutory corporate tax rate by approximately five percentage points (Agell et al., 1995), which is not included in the figure but is considered in our calculations. However, there was a fear among businessmen that the rules might be sharpened. Non-implemented proposals with the purpose of transferring private ownership to the funds-which had been suggested before the formal rules came in place-was seen as a threat to business for many owners (Henrekson \& Jakobsson, 2001, p. 352-354). This effect is not included in the METR because the King and Fullerton framework does not take business or political risks into account.

${ }^{24}$ See Lodin (2011, chapter 7) for further discussion about the design of the new corporate taxation.
} 
1990s. Inflation fell and was approximately 1 percent on average between 1994 and 2018.

Figure 2. The inflation rate, 1862-2018.

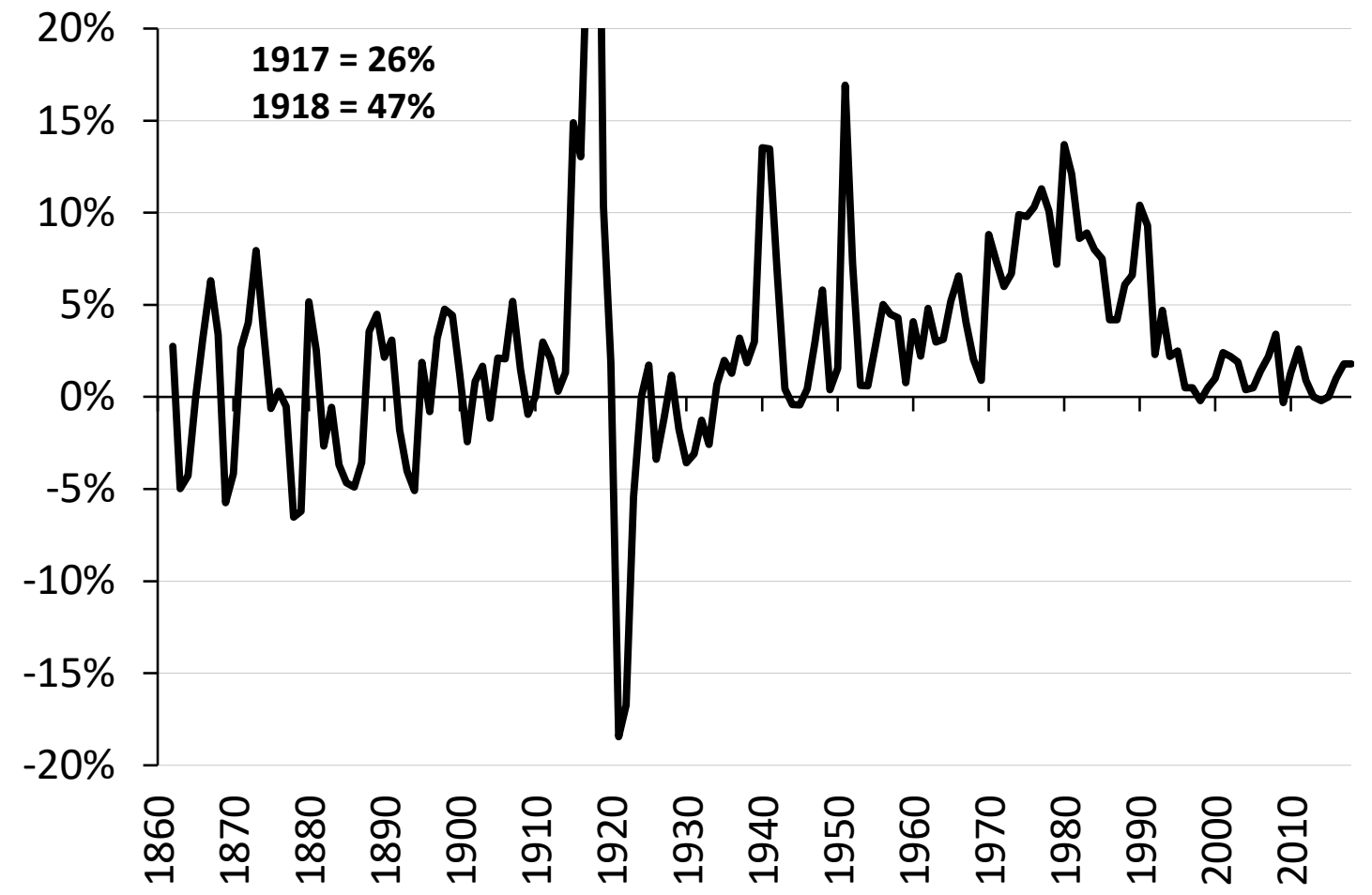

Source: http://www.scb.se/hitta-statistik/statistik-efter-amne/priser-ochkonsumtion/konsumentprisindex/konsumentprisindex-kpi/pong/tabell-ochdiagram/konsumentprisindex-kpi/inflation-i-sverige/

\section{The marginal effective tax rate on capital income (METR)}

This section will describe how the marginal effective tax rate on capital income (METR) is calculated for foundations (section 4.1), assumptions made (section 4.2) and how the METR has evolved over time between 1862 and 2018 for these foundations (section 4.3). 


\subsection{The model}

The aim of King and Fullerton (1984) is to investigate the METR on investment projects in the nonfinancial corporate sector using a framework that accounts for all capital income taxes, corporate taxes, wealth taxes and inflation that concern the investment decisions of the saver. The method should also be sufficiently generalizable to allow for the analysis and comparison of investment projects as well as of national tax systems.

According to King and Fullerton (1984), the METR can be calculated as the difference between the pre-tax return, $p$, and the post-tax return, $s$, divided by the pretax return:

$$
\operatorname{METR}=\frac{p-s}{p}
$$

In the model, there is a saver and a company. The company carries out the investment, and the saver receives a real rate of return:

$$
r=i-\pi
$$

where $i$ is the nominal interest rate, and $\pi$ is the inflation rate.

For any investment project, the cost of capital, $p$, is defined as the minimum rate of return it must yield before taxes to give the saver the same post-tax return as lending on the market:

$$
p=c(r)
$$

Equation (3) can be thought of in two ways: either as a capital market equilibrium that determines the marginal yield for a profit-maximizing company in an economy with a given interest rate $r$, or as the maximum interest rate $r$ that after taxes 
would make the saver indifferent between funding a project with a pre-tax yield $p$ and lending on the market. The first case is usually called fixed-r, and the second fixed-p. We will use a fixed- $p$ approach and conform to the standard with $p=10$ percent.

The relation between the return to the saver and the market interest rate depends on the tax code. Since taxation in Sweden depends on the nominal income, the relationship is defined as:

$$
s=(1-m)(r+\pi)-\pi-w
$$

where $m$ is the marginal tax rate on interest income and $w$ is the marginal tax rate on wealth. Without any taxes, there would be no differences between the variables, so that $s=r=p$.

Now, turning to the company, the value of an investment project $V$ is:

$$
V=\int_{0}^{\infty}(1-\tau) M R R e^{-(\rho+\delta-\pi) t} d t=\frac{(1-\tau) M R R}{\rho+\delta-\pi}
$$

where $M R R$ is the marginal rate of return on the investment project, $\rho$ is the discount rate and $\delta$ is the rate of depreciation.

The cost of a project $C$ is unity, with the exception of any grants or allowances $A$, so that:

$$
C=1-A
$$

Now, define $p$ as the return net of depreciation:

$$
p=M R R-\delta
$$

Now, combine (5)-(7) and solve for the discount rate:

$$
p=\left(\frac{1-A}{1-\tau}\right)(\rho+\delta-\pi)-\delta
$$


In the baseline scenario, tax depreciation is assumed to be a continuous exponential function decreasing at rate $a$, so that:

$$
A=\int_{0}^{\infty} \tau a e^{-(a+\rho) t} d t=\frac{\tau a}{a+\rho}
$$

Now, $\rho$ will depend on the source of finance.

For a saver, new share issues are only attractive as an investment if the paid discount rate $\rho$ after dividend tax $m_{d}$ is at least as profitable as lending on the market and paying interest rate tax $m$, so that:

$$
\left(1-m_{d}\right) \rho=(1-m) i \leftrightarrow \rho=i \frac{(1-m)}{\left(1-m_{d}\right)}
$$

In line with the model, retained earning enables an investor to accumulate at a rate of return taxed as capital gains. If $z$ is the effective marginal tax on capital gains, the following must hold: ${ }^{25}$

$$
(1-z) \rho=(1-m) i \leftrightarrow \rho=i \frac{(1-m)}{(1-z)}
$$

Since interest payments are tax deductible, the rate at which the company will discount the cash flow is the net of tax interest rate in the debt case:

$$
\rho=i(1-\tau)
$$

Altogether, by combining Equations (8) and (9), we can solve for $\rho$, and for each form of financing, we can compute the interest rate $i$ with Equations (10)-(12).

\footnotetext{
${ }^{25}$ The effective capital tax can be derived endogenously in the model. However this further complicates the calculations and depends on assumptions of the average holding period. For simplicity we assume the effective capital tax to be half of the statutory rate. The same assumption is made by King and Fullerton (1984, p. 146).
} 
Using Equations (2) and (4), we can calculate the post-tax return $s$. Finally, we insert this value for $s$ in Equation (1) and compute the METR.

\subsection{Assumptions}

Using the presented model and considering the rules and evolution of the tax system as presented in section 3, we can calculate the METR for private foundations, given new share issues, retained earnings and debt as sources of finance. However, as always when using a model, some assumptions must be made.

The corporate income tax rate is straightforward to use when the corporate income tax system is proportional. We will use the top tax rate when the system is progressive (1903-1939). ${ }^{26}$

The capital income tax rate is first set to zero, as private foundations are exempted from paying tax on their capital income. This is in line with the analysis performed in earlier studies (Jorgensen \& Landau, 1993; King \& Fullerton, 1984 and, for Sweden, Södersten 1984, 1993). However, private foundations are obliged to use the bulk of their capital income (less capital gains) for charity, as described in section 3 . This inflicts a cash flow effect that obstructs the ability to maintain control over the 'sphere companies' and hence provides a negative incentive for high-impact entrepreneurs to use private foundations as a means for control. In fact, this effect parallels the cash flow effect caused by capital income tax on dividends and interest. The cash flow effect is not discussed or considered in previous analyses. To illustrate the impact on the incentives to control firms through direct ownership or through private foundations, we will make a complementary calculation of the METR where the

\footnotetext{
${ }^{26}$ Using, for example, the lowest or the average of the highest and lowest tax rates will not change our general conclusions.
} 
requirement to donate part of the return to charitable purposes is treated as a tax. Though not formally correct, this calculation will capture the cash flow effect and further our understanding of the incentives to use private foundations to control companies. $^{27}$

The wealth tax rate is set to zero, as private foundations are exempted from wealth tax. Actual inflation rates are used in the calculations, as presented in section 3.3 .

There are special tax rules that must be accounted for during the period, e.g., the Annell deduction, the investment funds, a special additional allowance given between 1976 and 1978 and in 1980, and the SURV. Those will all in different ways lower the effective corporate taxation. The Annell deduction will, however, only reduce the corporate tax when new share issues are the source of finances. Between 1939 and 1951, immediate write-off was possible. Those rules and how they are incorporated are described in Johansson et al. (2018) and Wykman (2018).

\subsection{Results}

Figure 3 describes the METR with new share issues, retained earnings and debt as a source of finance. $^{28}$

The METR for equity financed investments was low and below 10 percent before World War I. It increased during World War I and in the interwar period. The top level was reached, with spikes exceeding 40 percent, during the 1950s. The METR for new share issues and retained earnings deviated between 1960 and 1993 because of

\footnotetext{
${ }^{27} \mathrm{~A}$ tax is formally defined as a compulsory contribution to state revenue without any direct and formal connection to a specific purpose or state expenditure.

${ }^{28}$ Our purpose is to study foundations as a means for control. As control is exercised through ownership, debt is a less relevant source of finance. For completeness with previous analyses, the results for debt financing are shown.
} 
the so-called Annell deduction, a tax credit given only to investments financed with new share issues. During the end of the period, the METR fluctuates between 10 and 15 percent.

Figure 3. The marginal effective tax rate (METR), private foundations, new share issues, retained earnings and debt, 1862-2018.

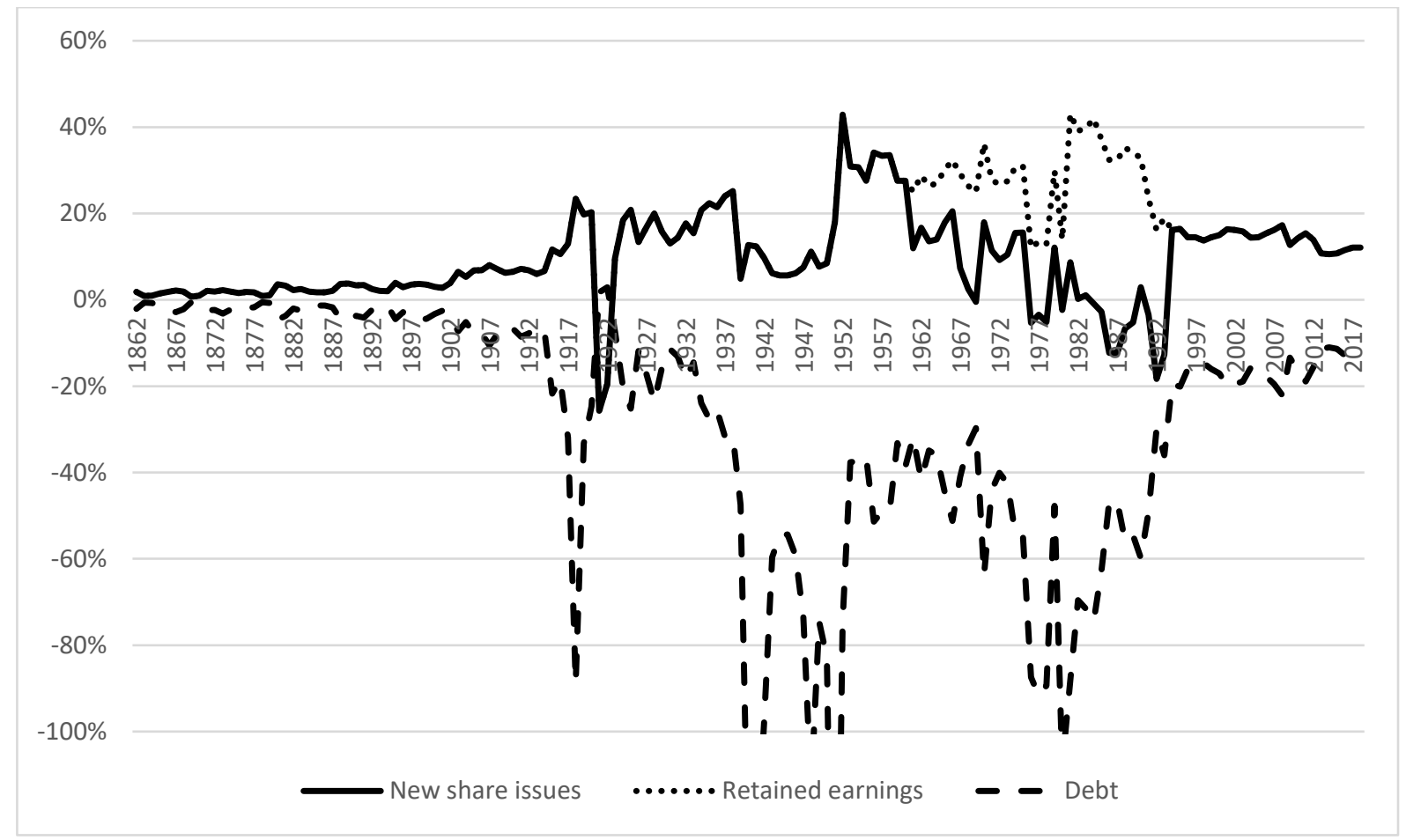

Note: The figure is truncated, and spikes up to 200 percent are excluded to increase visibility

Source: Own calculation.

The negative METR for debt financing is in line with findings of previous research (Södersten 1984, 1993) and is expected in a case with no taxation at the owner level in combination with deductible interest cost, write-offs and different tax credit at the firm level.

In the ordinary METR calculations, the income tax for the foundation is set to 0 percent. In a strict sense, this is a true interpretation because donating a part of one's income cannot be equated with a tax. However, as discussed above, it could be argued 
that this does not capture all incentives and that the associated METR may be misleading. The requirement to donate the bulk of the net income to charitable purposes will have a negative cash flow effect similar to a dividend tax. This effect is not addressed in the ordinary King and Fullerton framework, and the METR can be recalculated to include this effect.

This recalculation requires an assumption regarding how large a share of the net income the foundation must donate. As described earlier, no exact numbers are mentioned in the statutory law, and both case law and the specific circumstances of the foundation are relevant for the exact determination of how much of the income that has to be used for the charitable purposes during the whole period. Case law after World War II indicates that, on average, approximately 80 percent of the net return had to be spent on charitable purposes; we will use this figure in our calculations for the whole period.

Figure 4 depicts the results including this cash flow effect. In the case of new share issues, the METR fluctuates mostly around 100 and 150 percent, with occasional spikes up to 200 percent. The METR for retained earnings coincides with the earlier METR without any cash flow effect. Retained earnings enable investors to accumulate at a rate of return that is taxed by capital gains, and there is no cash flow effect because private foundations do not have to redistribute capital gains to charitable purposes. ${ }^{29}$ The difference between debt and new share issues is minor. Although the interest rate is deductible, the requirement to donate 80 percent dominates this effect, and the deduction only decreases the METR to a smaller extent.

\footnotetext{
${ }^{29}$ Recall the model description in section 4.1.
} 
Figure 4. The marginal effective tax rate (METR), private foundations, new share issues, retained earnings and debt, 1862-2018, including cash flow effect.

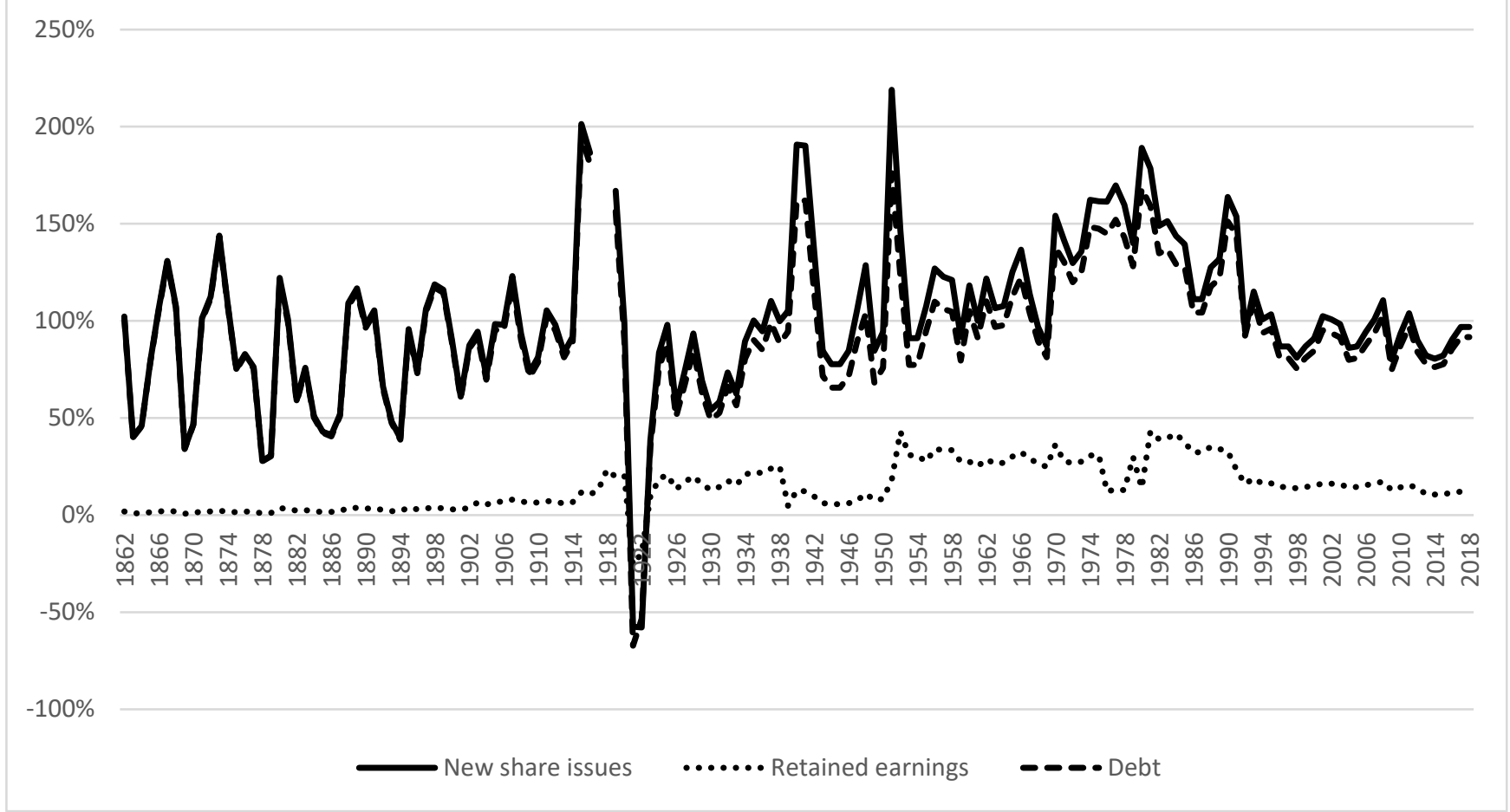

Note: The METR is calculated assuming that the foundation has to pay 80 percent of its net income to charitable purposes. The figure is truncated, and extreme spikes during World War I are excluded to increase visibility.

Source: Own calculation.

\section{Tax incentives for private foundations and high-impact entrepreneurs' ownership}

A person or a family can control firms by personal ownership; i.e., they can personally own the stocks, or they can control firms through a private foundation; i.e., they can transfer the shares to a private foundation that they control. For a better understanding of the incentives for controlling firms through private foundations, it is necessary to compare the METR for private foundations with the METR of personal ownership. Since the major holdings of the influential foundations are listed firms, we will compare 
the METR for foundations with that for the owners of listed companies. ${ }^{30}$

This section starts by comparing the METR for a private foundation with the METR for an owner of a listed firm, who pays the top marginal income and wealth tax (section 5.1). High-impact entrepreneurs are owners who have extraordinary incomes and wealth, and they can therefore be expected to pay top marginal tax rates. ${ }^{31} \mathrm{We}$ also include a comparison of the METR when the negative cash flow from the requirement to donate to charitable purposes is considered. The inheritance and gift tax is not included in the METR. However, it affects the incentive to control firms through private foundations. This is discussed in section 5.2.

\subsection{Comparison of the METR for private foundations and for high-impact entrepreneurs}

Figures 5-7 illustrate the difference in tax incentives between personal ownership and control through private foundations. In the case of new share issues (see Figure 5), there were non-existent or small tax incentives to exercise control through private foundations in the first 50 years of our study, and the cash flow effect provided clear negative incentives. The tax incentives to control firms through foundations became stronger between World War I and the tax reform in 1990-1991. The cash flow effect gave a weak negative incentive until the beginning of the 1940s, when increased taxation on dividends neutralized the cash flow effect. Further increases in taxes on dividends gave cash flow incentives to use private foundations as a means of control during the late

\footnotetext{
${ }^{30}$ Special rules for closely held corporations were introduced in the 1990-1991 tax reform (e.g., Wykman, 2018). Calculating the METR for owners of closely held firms does not qualitatively affect our conclusions, and to avoid cluttering in the figures and for parsimonious reasons, we restrict the comparison to the owners of listed firm.

${ }^{31}$ Research indicates that high-impact entrepreneurship is critical for economic development (Acs, 2008; Coad et al., 2014; Henrekson \& Johansson, 2010; Henrekson \& Sanandaji, 2014; Henrekson \& Stenkula, 2017). It also seems that high-impact entrepreneurs are more sensitive to taxation than are other entrepreneurs (Henrekson \& Johansson, 2008; Henrekson et al., 2010).
} 
1970s and early 1980s. After the 1990-1991 tax reform, the difference in the METR was heavily reduced, and the cash flow effect provided negative incentives to transfer ownership to private foundations.

Figure 5. The marginal effective tax rate (METR), private foundations and high-impact entrepreneurs, new share issues, 1862-2018.

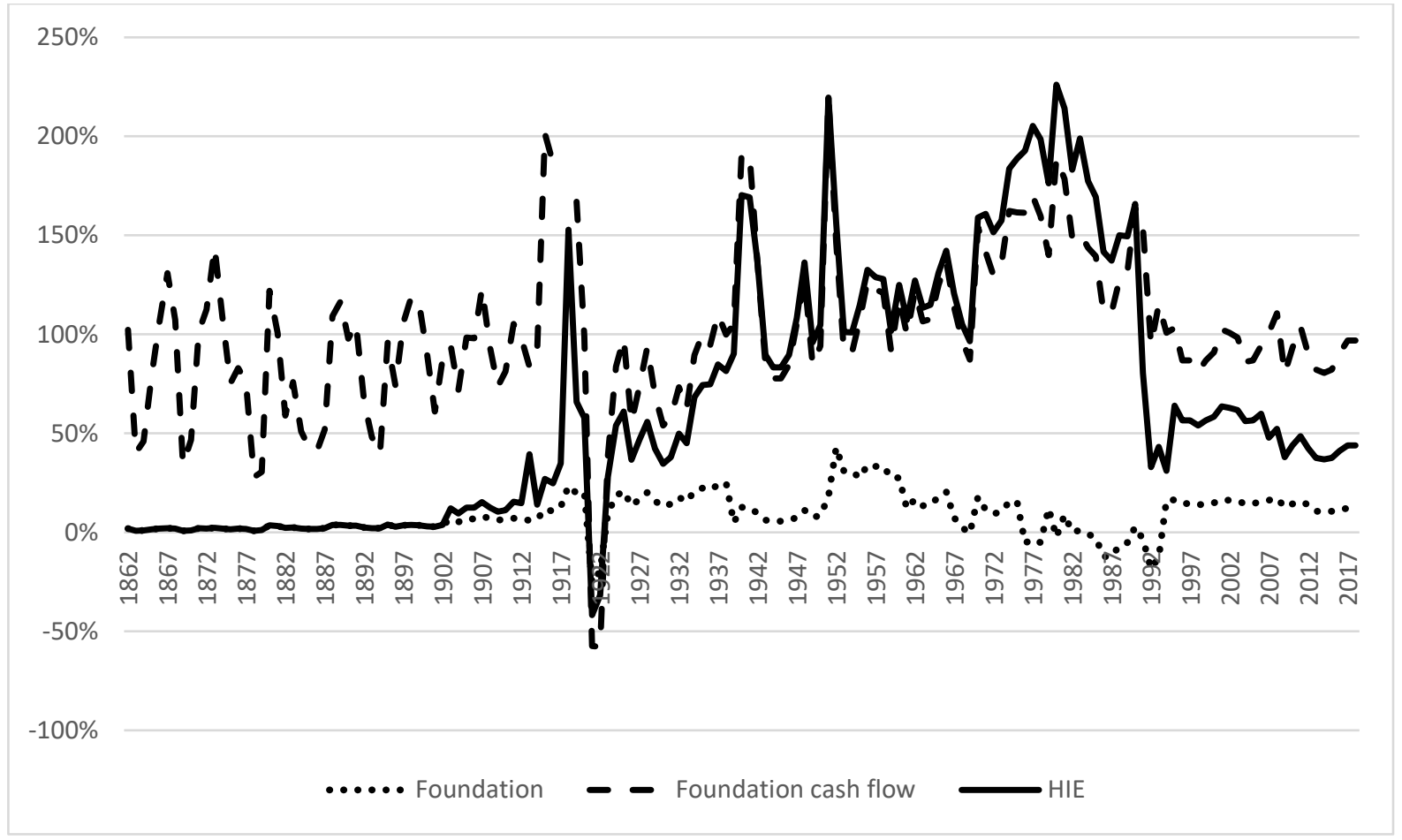

Note: Foundation cash flow considers the requirement that a private foundation has to donate the bulk of dividend income ( 80 percent is used in our calculations) to charitable purposes, which parallels the negative cash flow caused by dividend taxation. HIE refers to a high-impact entrepreneur who owns a listed firm and pays the top marginal tax rates.

Source: Own calculations, Johansson et al. (2015) and updating. 
Figure 6. The marginal effective tax rate (METR), private foundations and high impact entrepreneurs, retained earnings, 1862-2018.

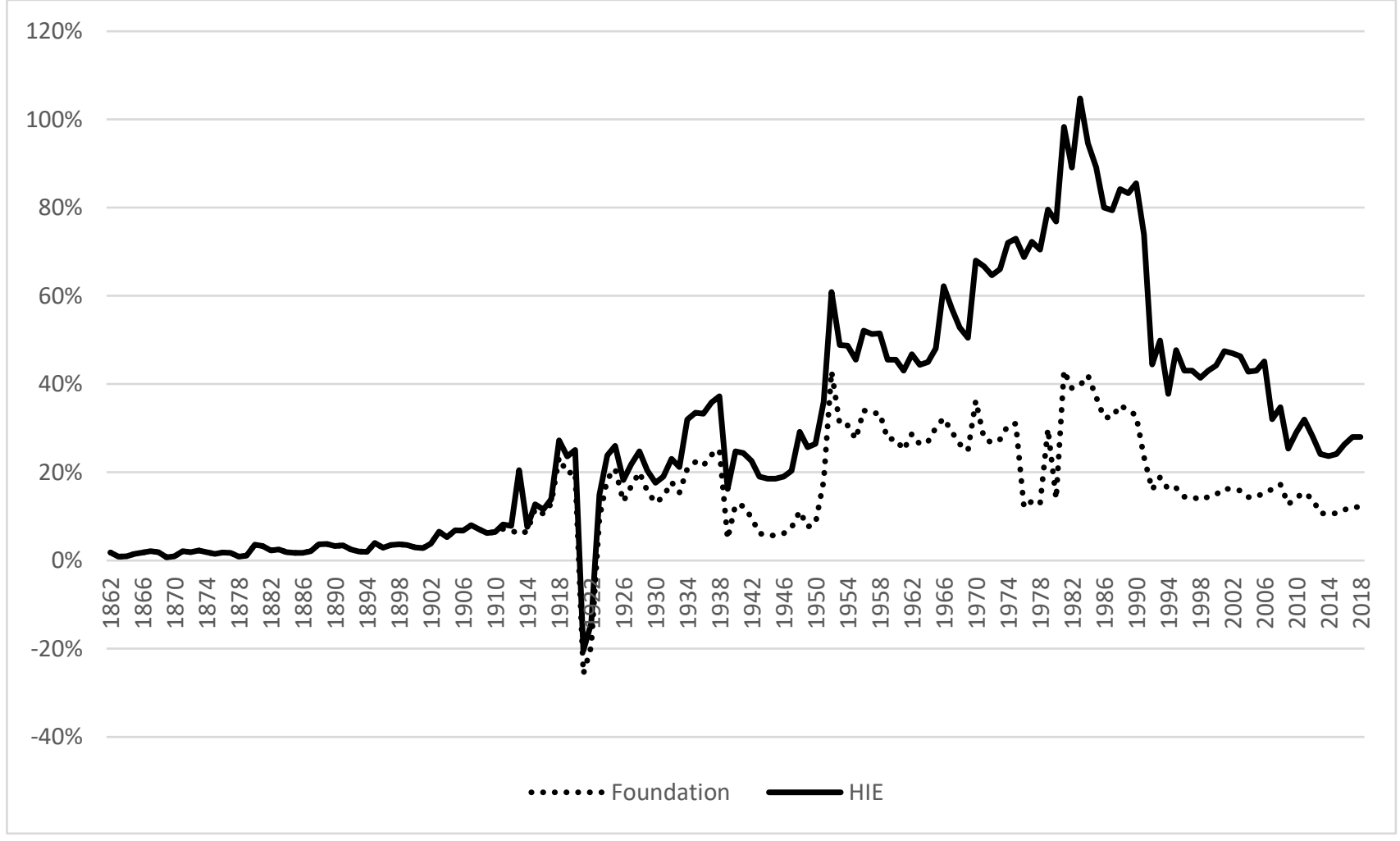

Note: HIE refers to a high-impact entrepreneur who owns a listed firm and pays the top marginal tax rates. There is no cash flow effect because private foundations do not have to redistribute capital gains to charitable purposes.

Source: Own calculations, Johansson et al. (2015) and updating.

In the retained earning case, incentives to use private foundations for control were non-existent or small until the mid-1960s because capital gains on long-term holdings were tax exempt for natural persons until 1966 (see Figure 6). The METR was therefore the same for private foundations and high-impact entrepreneurs until the introduction of the wealth tax, which somewhat increased the METR for personal ownership compared to foundations.

In 1966, when the taxation of natural persons' capital gains on long-term holdings was introduced, the METR began to diverge substantially, and the incentives to use private foundations as means for control increased. The METR increased further 
for the entrepreneur when the capital gains and wealth taxations were sharpened. The entrepreneur's METR peaked in 1983 and decreased during the rest of the 1980s.

Nevertheless, the tax incentives for using private foundations were high from the mid1960s until the 1990-1991 tax reform, which substantially reduced the METR for highimpact entrepreneurs. ${ }^{32}$ The abolishment of the wealth tax in 2007 further decreased the high-impact entrepreneur's METR, and since then, the difference in the METR between the entrepreneur and the foundation has been approximately 10 percentage points.

Finally, we turn to the debt case in Figure 7. Foundations had no tax advantage before World War I. After the War, particularly since the end of the 1930s and throughout the entire period until the 1990s, there was a strong incentive to use private foundations as a means of control, ignoring the cash flow effect. The sharp spikes in the figures during World War I, for example, are due to inflation (and deflation) peaks. With higher inflation, companies will compensate the investor with a higher interest rate (which ceteris paribus reduces the METR), but they affect taxed versus non-taxed owners differently. If the nominal interest income is highly taxed, the rise in income will not be enough to outweigh the personal cost of inflation. Hence, tax-privileged owners will benefit from the higher interest rates companies have to pay when inflation is high. ${ }^{33}$

\footnotetext{
${ }^{32}$ Lower inflation contributed to reducing the METR for high-impact entrepreneurs as well as for foundations.

${ }^{33}$ This is driven by the tax wedge between corporate and personal income taxation. If both taxes are zero, the inflation will not affect the METR. Generally, if the two taxes are equal, inflation will not affect the METR. However, when there is a difference between corporate and personal income taxation, inflation will raise or lower the METR. When the personal interest tax is higher than the corporate tax, a higher inflation will raise the METR. Since the corporate tax is deductible and payments are nominal, the company will raise its payments equal to the inflation pre-corporate tax; the owner will tax this nominal payment at a higher tax rate and, hence, obtain a higher METR (since it is a real metric). If the corporate tax is higher than the personal tax, the opposite will be true.
} 
Figure 7. The marginal effective tax rate (METR), private foundations and high-impact entrepreneurs, debt, 1862-2018.

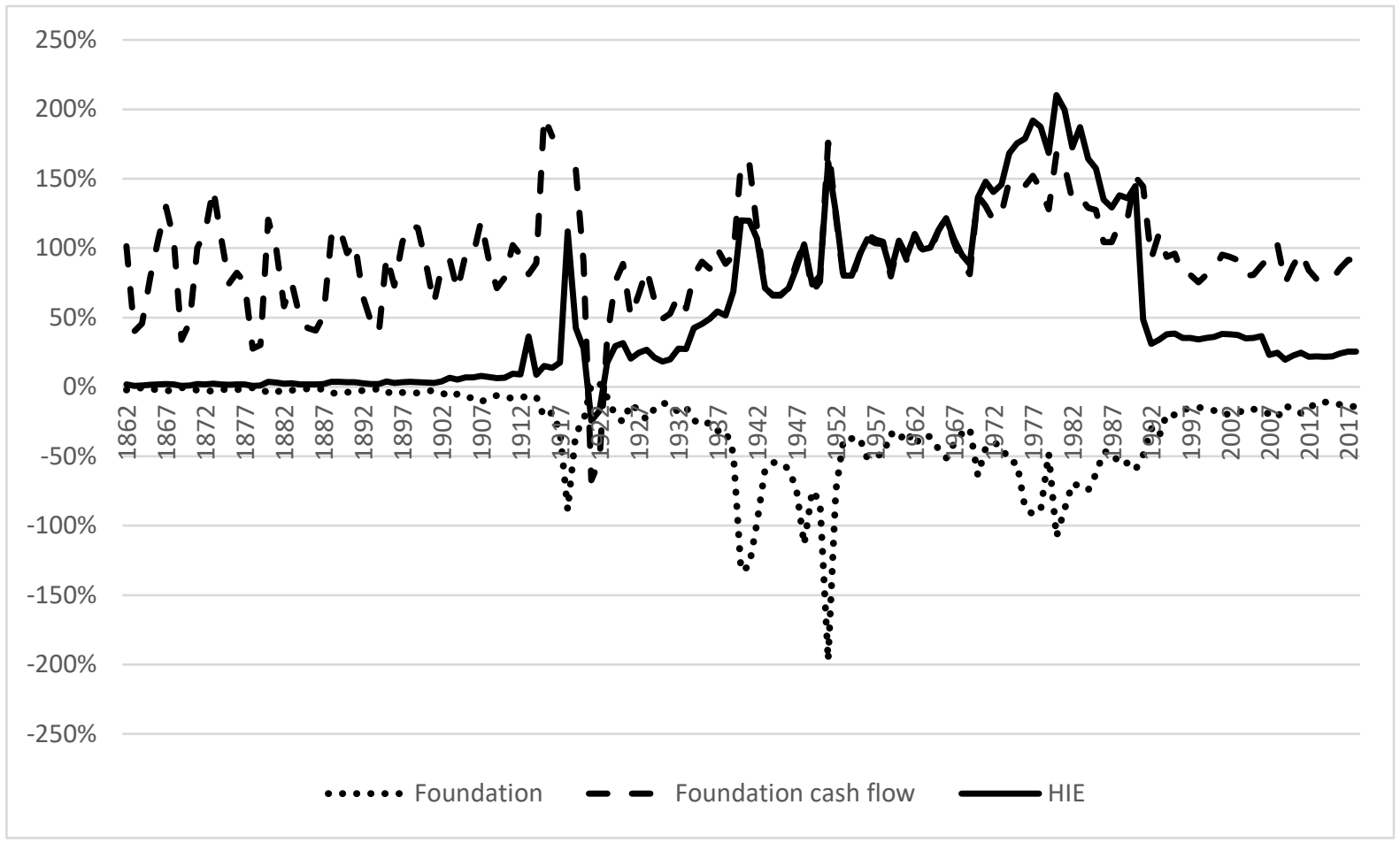

Note: Foundation cash flow accounts for the requirement that a private foundation has to donate the bulk of interest income (80 percent is used in our calculations) to charitable purposes, which parallels the negative cash flow caused by interest taxation. HIE refers to a high-impact entrepreneur who owns a listed firm and pays the top marginal tax rates.

Source: Own calculations, Johansson et al. (2015) and updating.

Focusing on the negative cash flow, personal ownership was preferable until World War II, when increased top marginal tax rates on interest income removed the advantage of personal ownership. Further increases in the top marginal tax rates created cash flow incentives to use private foundations as a means of control during the late 1970s and early 1980s. The 1990-1991 tax reform sharply reduced the tax incentives for private foundations' control and once again gave cash flow incentives for personal ownership. 
In sum, taking tax incentives and cash flow effect into account, personal ownership is preferable until World War I, regardless of the source of finance. During the interwar period, the results are mixed; private foundations were tax favoured, but financing the investment with new share issues or debt brought about a negative cash flow effect. After World War II and until the 1990-1991 tax reform, the total effect from taxation, cash flow and source of finance favoured control through private foundations. Tax and cash flow incentives generally favoured personal ownership for controlling firms after the tax reform.

A complementary analysis is to decompose the true return on ownership into dividends and price changes on the underlying stocks, i.e., capital gains, and use that as the basis for the calculation of the incentives. The share of dividend yields of the return on the public stock market for the period 1870-2012 is, on average, approximately 40 percent (Waldenström, 2014), and we calculated the METR using this number (see Appendix C). This does not affect the conclusions regarding the incentives to use private foundations as a means for control.

As a final point, it is worth noting the relatively stable tax conditions for foundations compared to personal ownership. This could in itself be an incentive to transfer wealth to foundations. Comparing the development of the tax rules for foundations with those for personal ownership, it seems reasonable to assume that investors felt more confident that the tax rates for foundations would remain stable over time, while over a long period of time, other tax rates seemed to increase constantly.

\subsection{The inheritance and gift tax}

The inheritance and gift tax is excluded in the METR, but such taxes may impact the incentives to transfer the ownership of firms to private foundations. For instance, 
Schumpeter (1934, p. 93) was of the opinion that dynastic ambitions were a key

incentive for entrepreneurs, which has been supported by current research, e.g., GómezMejía et al. (2007). Our examination of the large influential family groups shows that dynastic ambitions are critical to understanding firm control. Descendants of the highimpact entrepreneurs that established the groups are still in control; e.g., the Wallenberg group is controlled by the fifth generation, the Ax:son Johnson group by the fourth and fifth, the Lundberg group by the second and third, the Douglas group by the second and the Schörling group by the second.

Modern inheritance taxation was introduced in Sweden in 1885. The tax system distinguished between different classes of heirs. Surviving spouse, cohabiter, children and descendants paid the lowest tax rates, while parents, siblings and others had higher tax rates (Du Rietz et al., 2015). Figure 8 shows the top marginal inheritance tax for shares registered on a stock exchange and for class I heirs (i.e., children, spouses and descendants). The tax level was modest, 0.5 percent, when the inheritance tax was introduced, but it increased over time. The top marginal tax rate was sharply increased to 20 percent in 1934 and to 60 percent in 1948. In the early 1970s, the tax rate peaked at 65 percent before the statutory tax rate started to decrease, and different forms of tax relief were introduced. The top marginal tax rate for publicly listed shares was halved to 22.5 percent in 1992, and the inheritance tax was completely abolished as of December $17,2004 .^{34}$

\footnotetext{
${ }^{34}$ During the period 1978-1996, 75 percent of the market value was to be taxed, and during the period 1997-2004, 80 percent was. A valuation relief was introduced for small non-listed firms in 1971 to facilitate the takeover of family firms by heirs. In 1978, the relief became more generous, and small firms were valued at 30 percent of the book net equity value. This rule was in force until the inheritance tax was abolished.
} 
Figure 8 . The top inheritance marginal tax rate for shares registered on a stock exchange, class I, 1885-2004.

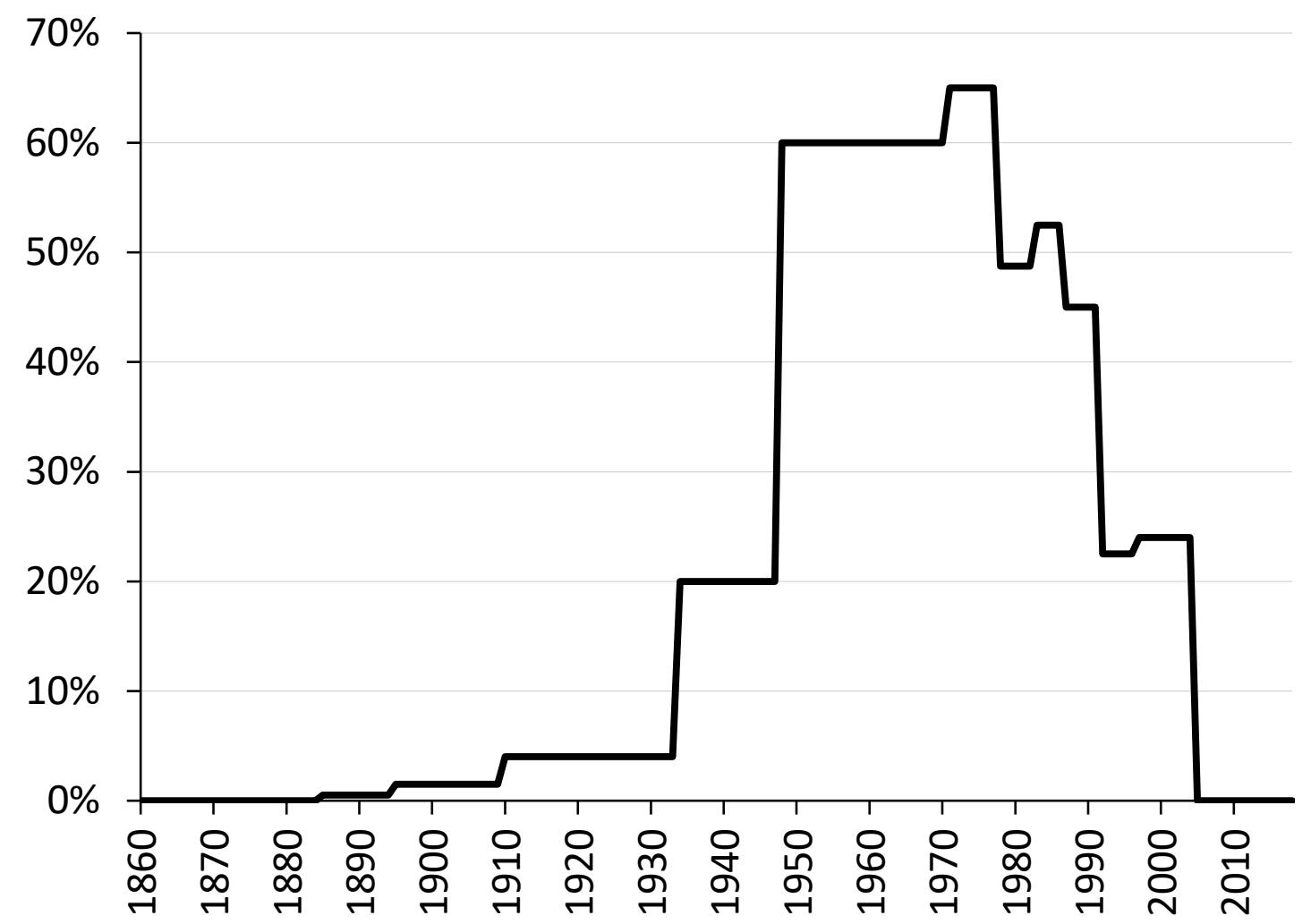

Note: Class I includes children, spouses and descendants. During the period 1978-1996, 75 percent of the market value was to be taxed, and during the period 1997-2004, 80 percent was.

Source: Tax tables reproduced in Du Rietz et al. (2015).

High-impact entrepreneurs' wealth is mainly composed of their stocks. Heirs may therefore have to sell shares to pay the inheritance tax. They may then have to pay capital gains tax, which further increases the tax burden on inheritance.

Hence, the tax incentive to transfer the ownership of large firms to private foundations was strong for the period between the 1948 tax reform-when the top marginal statutory tax rate on inheritance increased sharply to 60 percent-and the 1990-1991 tax reform-when the top marginal statutory tax rate on inheritance for listed shares decreased sharply to 22.5 percent-i.e., for more than four decades. The 
transfer of capital to private foundations has also been common in connection with generational shifts after World War II to avoid inheritance tax (SOU 1968:7).

\subsection{Discussion}

The influential family groups that used private foundations as a means for control were involved in high-impact entrepreneurship in Swedish industrialization, levelling off in the mid/late $19^{\text {th }}$ century. The private foundations of major economic significance were established by these entrepreneurs or their descendants between World War I and the 1960s. Furthermore, the new family groups that currently have major influence in Swedish industry do not rely on private foundations as a means for control but prefer personal ownership. Our analysis helps to explain why.

There were no tax incentives to control firms by private foundations until World War I. The incentives gradually increased during and after the war because of increased taxation on personal capital income, wealth, inheritance and gifts. These taxes were raised to such levels after World War II that individual ownership of large firms by entrepreneurs was extremely unfavourable, as was the transfer of large firms to the next generation. ${ }^{35}$ Firms that had grown large before the sharpened tax policy could still be kept under family control by transferring the ownership to a private foundation controlled by the family.

However, new successful firms could hardly be established and grow large during this tax regime. The high tax burden and the wage-earner funds made potential high-impact entrepreneurs leave the country if they wanted to realize their growth

\footnotetext{
35 This was a result of deliberate economic policy to convert companies to 'social enterprises without owners'. It has been described as a policy aiming at a 'capitalism without capitalists' (Henrekson \& Jakobsson, 2001; Johansson \& Magnusson, 1998, p. 115-116).
} 
ambitions and keep control over their firms. ${ }^{36}$ Hence, there were basically no new large fortunes created by high-impact entrepreneurs domiciled in Sweden. Consequently, there was no substantial wealth that could be transferred to private foundations and provide the basis for the control of significant shares of Swedish industry. This helps explain why there were no private foundations of economic significance founded by new high-impact entrepreneurs or their families after World War II. It also helps to explain why no influential private foundations were established during the 1970s and 1980s. 'Old' families had already transferred their wealth to private foundations to safeguard control, and no new wealth had been created that could be transferred. ${ }^{37}$

The establishment of the still influential Knut och Alice Wallenbergs Stiftelse, Axel och Margaret Ax:son Johnsons Stiftelse för allmännyttiga ändamål and Axel och Margaret Ax:son Johnsons Stiftelse is of particular interest for our study. Knut A. Wallenberg (KAW) was a well-known philanthropist who had donated considerable sums to charitable purposes. According to himself, he established the foundation because he was 'fed up' with personally having to administer a large and increasing number of begging letters. By establishing the foundation, he could reject all proposals and refer all beggars to the foundation (Olsson, 2006).

Although not stated in his official motivation, it is plausible that he, as a most successful entrepreneur, also considered financial and tax issues. He and his wife, Alice, had no children of their own, and the closest heirs, his brothers, would have to pay higher inheritance tax than class I heirs. Olsson (2006, p. 342) also reports that Knut

\footnotetext{
${ }^{36}$ The most well-known examples are IKEA (the founder Ingvar Kamprad emigrated in 1972) and Tetra Pak (the founder Ruben Rausing emigrated in 1969 and his two sons Gad and Hans in 1982). Fredrik Lundberg emigrated in 1985 but returned in 1993 after the 1990-1991 tax reform and the abolishment of wage-earner funds (Henrekson, 2005, 2017; Henrekson \& Johansson, 1999; Henrekson \& Stenkula, 2015; Heshmati et al., 2010).

${ }^{37}$ See Henrekson and Jakobsson $(2001,2005)$ and Henrekson (2017) for further discussion on the difficulties for entrepreneurs to grow companies large and create wealth after World War II, and particularly during the 1970s and 1980s.
} 
had to pay 1.2 percent of his total wealth in tax in 1913, including the 1913 defence tax. The defence tax was designed to apply exclusively to very large incomes and fortunes (Söderberg, 1996, p. 11), in effect, targeting a few individuals controlling large parts of the Swedish industry. Surtaxes similar to the 1913 defence tax were levied in 1918 and 1919. KAW served as Minister of Foreign Affairs during the war, meaning that he was well aware of discussions of how to finance the war effort. According to Olsson (2006) and Du Rietz and Henrekson (2015, p. 273), he managed to avoid paying the 1918 and 1919 surtaxes and subsequent wealth taxes by donating the bulk of his fortune to the private foundation, Knut och Alice Wallenbergs Stiftelse. Hence, it does not seem too farfetched to argue that taxation was one reason for the establishment of the foundation.

The increased taxation, particularly that concerning inheritance, explicitly motivated the establishment of Axel och Margaret Ax:son Johnsons Stiftelse för allmännyttiga ändamål and Axel och Margaret Ax:son Johnsons Stiftelse in 1947 (de Geer 1998, p. 209ff.; Feldt, 2012).

The 1990-1991 tax reform, the abolishment of wealth tax on non-listed firm equity in 1991, the abolishment of wage-earner funds in 1992 (introduced in 1984), the abolishment of wealth tax in 2004 and the abolishment of inheritance and gift tax as from 2007 made the tax system more neutral. In fact, personal ownership is cash flow favoured because private foundations have to distribute most of their capital income to charitable purposes. Moreover, controlling firms through private foundations implies that ownership of the firm has to be transferred from the entrepreneur to the foundation. There is also a lock-in effect; entrepreneurs can move from Sweden, while foundations cannot. In line with changed incentives, new influential family groups do not rely on private foundations as a means for control. 


\section{Concluding remarks}

This study has described the evolution of tax rules for private foundations, calculated the marginal effective tax rate on capital income (METR) for private foundations and compared the taxation of private foundations with the taxation of a high-impact entrepreneur owning a listed firm and paying the top marginal tax. The METR includes the effects of corporate income taxation, capital income taxation and wealth taxation and the interactions of these taxes with inflation. It is calculated for an investment financed with new share issues, retained earnings or debt. The investigation covers the years 1862 to 2018 .

Private foundations have been used by a few influential ownership spheres to exercise far-reaching control over Swedish industry. Currently, the private foundations controlled by the Wallenberg and Ax:son Johnson families still have substantial ownership stakes in Swedish industry.

Private foundations do not have to pay taxes on capital income, wealth or inheritance and gifts. On the other hand, this tax-exemption requires that they donate the bulk of their net capital income (less capital gains) to charitable purposes, which brings about a negative cash flow that reduces the ability to retain control over companies and parallels the capital income tax on dividends. ${ }^{38}$ The donation requirement therefore creates a disincentive to control firms through private foundations. The requirement could be circumvented by selling shares instead of receiving dividends. However, this comes at the cost of losing control and has therefore generally been avoided. As in earlier analyses, the donation requirement could be disregarded, but its lack of consideration could be misleading if there is an interest in understanding the ownership

\footnotetext{
${ }^{38}$ The exact share that must be donated is not regulated in law, but custom that has evolved requires the donation of approximately 80 percent of the net capital income, excluding capital gains.
} 
and control of Swedish industry. To illustrate the impact on the incentives to control firms through personal ownership or through private foundations, we therefore make a complementary analysis where the donation requirement is included in the METR calculations.

The analysis has shown that the METR was approximately the same for private foundations and for high-impact entrepreneurs for the first 50 years of our study. Taking the cash flow effect from the donation requirement into account, personal ownership was preferable. No foundations of economic significance were founded during this period.

Tax incentives for control through private foundations increased during and after World War I. After World War II, the increased capital income, wealth and inheritance and gift taxes made it difficult to keep and transfer large family firms to the next generation. Hence, private foundations had a tax advantage compared to high-impact entrepreneurs until the 1990-1991 tax reform. The increased taxation of dividend income also levelled the negative cash flow from the donation requirement. All of the influential private foundations were established between World War I and the 1960s by wealth originating from Swedish industrialization starting in the mid-/late $19^{\text {th }}$ century.

The tax policy between World War II and 1991 made it hard for new entrepreneurs to create substantial wealth through private enterprising. The threat from wage-earner funds, originally aiming at transferring private ownership to collective control, created further disincentives. High-impact entrepreneurs had to leave the country to be able to realize their growth ambitions. This helps explain why no major private foundations were established during the 1970s and 1980s. Wealth that originated before World War II had already been transferred to private foundations, and little 
domiciled new wealth had been generated that could provide the basis for new influential foundations.

After the 1990-1991 tax reform, which profoundly decreased the capital income tax, the abolishment of the inheritance and gift tax in 2004 and the abolishment of the wealth tax in 2007, there were no tax incentives for high-impact entrepreneurs to control firms through private foundations. The donation requirement creates a negative cash flow effect compared to personal ownership. Using private foundations as a means for control also locks in capital in Sweden because foundations cannot move to other countries like individuals can. Taken together, private foundations have currently lost importance as a substitute for personal ownership in Swedish industry, and new family groups do not rely on private foundations as a means of control. To conclude, the taxation of private foundations versus personal ownership is one explanation for the rise of private foundations as a means of control of Swedish industry during the studied period. 


\section{References}

Acs, Z. J. (2008). Foundations of high impact entrepreneurship. Foundations and Trends in Entrepreneurship, 4(6), 535-620.

Agell, J., Englund, P., \& Södersten, J. (1995). Svensk skattepolitik i teori och praktik. In SOU 1995:104 (Skattereformen 1990-1991: En utvärdering). Stockholm: Fritzes.

Andersson, F. W., Johansson, D., Karlsson, J., Lodefalk, M., \& Poldahl, A. (2018). The characteristics of family firms: Exploiting information on ownership, kinship, and governance using total population data. Small Business Economics, 51(3), $539-556$.

Coad, A., Daunfeldt, S. O., Hölzl, W., Johansson, D., \& Nightingale, P. (2014). Highgrowth firms: Introduction to the special section. Industrial and Corporate Change, 23(1), 91-112.

County Administrative Board. Länsstyrelsernas gemensamma stiftelsedatabas. Retrieved from http://web05.lansstyrelsen.se/stift/StiftWeb/SSearch.aspx

Dagens Industri (06-12-2017). Börsens dolda maktelit: Sveriges tyngsta stiftelser äger aktier för 257 miljarder, pp. 6-7.

de Geer, H. (1998). Firman: Familj och företagande under 125 år: Från A. Johnson \& Co till Axel Johnsongruppen. Stockholm: Institutet för Ekonomisk-Historisk Forskning vid Handelshögskolan i Stockholm i samarbete med Atlantis.

Du Rietz, G., \& Henrekson, M. (2015). Swedish wealth taxation (1911-2007). In M. Henrekson \& M. Stenkula (Eds.), Swedish taxation: Developments since 1862 (pp. 267-302). New York: Palgrave Macmillan US.

Du Rietz, G., Henrekson, M., \& Waldenström, D. (2015). Swedish inheritance and gift taxation, 1885-2004. In M. Henrekson \& M. Stenkula (Eds.), Swedish taxation: Developments since 1862 (pp. 223-265). New York, NY: Palgrave McMillan.

Edvinsson, T. N. (2005). Att leda storföretag: En studie av social kompetens och entreprenörskap i näringslivet med fokus på Axel Ax:son Johnson och J. Sigfrid Edström, 1900-1950 (Dissertation). Stockholm: Stockholm University.

Feldt, K.-O. (2012). Den blyge entreprenören: Om bergsingenjör Axel Ax:son Johnson. Stockholm: Ekerlids. 
Glete, J. (1994). Nätverk i näringslivet: Ägande och industriell omvandling i det mogna industrisamhället 1920-1990. Stockholm: SNS (Studieförbundet Näringsliv och Samhälle).

Gómez-Mejía, L. R., Haynes, K. T., Núñez-Nickel, M., Jacobson, K. J. L., \& MoyanoFuentes, J. (2007). Socioemotional wealth and business risks in familycontrolled firms: Evidence from Spanish olive oil mills. Administrative Science Quarterly, 52(1), 106-137.

Government bill 2013/2014:1. Stockholm: Finansdepartementet.

Gunne, C., \& Löfgren, J. (2014). Beskattning av stiftelser och ideella föreningar. Uppsala: Nordstedts Juridik AB, 3rd edition.

Hagstedt, J. A. (1972). Om beskattning av stiftelser (Dissertation). Uppsala: Uppsala University.

Henrekson, M. (2005). Entrepreneurship: A weak link in the welfare state? Industrial and Corporate Change, 14(3), 437-467.

Henrekson, M. (2017). Taxation of Swedish firm owners: The great reversal from the 1970s to the 2010s. Nordic Tax Journal, 1(1), 26-46.

Henrekson, M., \& Jakobsson, U. (2001). Where Schumpeter was nearly right-the Swedish model and capitalism, socialism and democracy. Journal of Evolutionary Economics, 11(3), 331-358.

Henrekson, M., \& Jakobsson, U. (2005). The Swedish model of corporate ownership and control in transition. In H. Huizinga \& L. Jonung (Eds.), Who will own Europe? The internationalisation of asset ownership in Europe (pp. 207-246). Cambridge, MA: Cambridge University Press.

Henrekson, M., \& Johansson, D. (1999). Institutional effects on the evolution of the size distribution of firms. Small Business Economics, 12(1), 11-23.

Henrekson, M., \& Johansson, D. (2008). Competencies and institutions fostering highgrowth firms. Foundations and Trends in Entrepreneurship, 5(1), 1-80.

Henrekson, M., \& Johansson, D. (2010). Gazelles as job creators: A survey and interpretation of the evidence. Small Business Economics, 35(2), 227-244.

Henrekson, M., Johansson, D., \& Stenkula, M. (2010). Taxation, labor market policy and high-impact entrepreneurship. Journal of Industry, Competition and Trade, 10(3-4), 275-296. 
Henrekson, M., \& Sanandaji, T. (2014). Small business activity does not measure entrepreneurship. Proceedings of the National Academy of Sciences of the United States of America, 111(5), 1760-1765.

Henrekson, M., \& Stenkula, M. (2015). Swedish taxation: Developments since 1862. New York, NY: Palgrave McMillan.

Henrekson, M., \& Stenkula, M. (2017). Understanding entrepreneurship: Definition, function and policy. Lund: Studentlitteratur.

Hermansson, C.-H. (1959). Koncentration och storföretag. Stockholm: Arbetarkultur.

Hermansson, C.-H. (1971). Monopol och storfinans - de 15 familjerna. Stockholm: Rabén och Sjögren.

Heshmati, A., Johansson, D., \& Bjuggren, C. M. (2010). Effective corporate tax rates and the size distribution of firms. Journal of Industry, Competition and Trade, 10(3-4), 297-317.

Johansson, A. L., \& Magnusson, L. (1998). LO andra halvseklet: Fackföreningsrörelsen och samhället. Stockholm: Atlas.

Johansson, D., Stenkula, M., \& Du Rietz, G. (2015). Capital income taxation of Swedish households, 1862-2010. Scandinavian Economic History Review, 63(2), 154-177.

Johansson, D., Stenkula, M., \& Wykman, N. (2018). Swedish capital income taxation of owners of closely held corporations, 1862 to 2018. Mimeo: Örebro University.

Jorgensen, D., \& Landau, R. (1993). The tax reform and the cost of capital: An international comparison. Washington, DC: Brookings Institution.

King, M., \& Fullerton, D. (1984). The taxation of income from capital: A comparative study of the United States, the United Kingdom, Sweden and West Germany. Chicago, IL: University of Chicago press.

Lindgren, H. (2007). Jacob Wallenberg 1892-1980. Stockholm: Atlantis.

Lodin, S.-O. (2011). The Making of Tax Law. Uppsala: Iustus förlag.

Nilsson, G. B. (1984). André Oscar Wallenberg. 1, odysséernas år 1816-1856. Stockholm: Norstedts.

Nilsson, G. B. (1989). André Oscar Wallenberg. 2, Gyllene tider 1856-1866. Stockholm: Norstedts.

Nilsson, G. B. (1994). André Oscar Wallenberg. 3, ett namn att försvara 1866-1886. Stockholm: Norstedts. 
Öberg, A. (2003). Essays on capital income taxation in the corporate and housing sectors. Uppsala economic studies 72 (Dissertation). Uppsala: Uppsala University.

Olsson, U. (2006). Finansfursten K. A. Wallenberg 1853-1938. Stockholm: Atlantis.

Persson-Tanimura, I. (1988). Marknadsmakt och ägarmakt - ett 20-årsperspektiv. Ekonomisk Debatt, 16(8), 625-633.

Schumpeter, J. A. (1934 [1912]). The theory of economic development: An inquiry into profits, capital, credit, interest, and the business cycle, trans. Redvers Opie. Cambridge, MA: Harvard University Press.

SFS (Swedish Code of Statutes) No. 1994:1220. Stiftelselag [Foundation Act]. Stockholm: Finansdepartementet.

Sjögren, H. (2017). Familjedynastier: Så blev Sverige rikt. Stockholm: Volante.

Söderberg, H. (1996). Inkomstskattens utveckling under 1900-talet: En vägvisare för skatteberäkningar åren 1921-1996. Stockholm: Skattebetalarnas Förening.

Södersten, J. (1984). Sweden. In M. King \& D. Fullerton (Eds.), The taxation of income from capital: A comparative study of the United States, the United Kingdom, Sweden and West Germany (pp. 87-148). Chicago, IL: University of Chicago Press.

Södersten, J. (1993). Sweden. In D. Jorgensen \& R. Landau (Eds.), The tax reform and the cost of capital: An international comparison (pp. 270-299). Washington, DC: Brookings Institution.

SOU 1939:47. Betänkande med förslag rörande beskattning av stiftelser och ideella föreningar $m$. fl. juridiska personer $m$. $m$. Stockholm: Finansdepartementet.

SOU 1968:7. Ägande och inflytande i det privata näringslivet, Koncentrationsutredningen. Stockholm: Finansdepartementet.

SOU 1995:63. Översyn av skatteregler för stiftelser och ideella föreningar. Stockholm: Fritzes.

SOU 2009:65. Moderniserade skatteregler för ideell sektor. Stockholm: Fritzes.

Stenkula, M. (2014). Swedish taxation in a 150-year perspective. Nordic Tax Journal, 2014(2), 10-42.

Stenkula, M., Johansson, D., \& Du Rietz, G. (2014). Marginal taxation on labour income in Sweden from 1862 to 2010. Scandinavian Economic History Review, 62(2), 163-187. 
Stenshamn, A. (1967). Beskattning av ideella föreningar och stiftelser. Stockholm: Bokförlaget Forum AB.

Sundqvist, S.-I. (1985-2015). Owners and power in Sweden's listed companies. Stockholm: SIS Ägarservice AB; 1994-2002 with Sundin, Anneli; 2003-2011 with Fristedt, Daniel and 2012-2014 with Fristedt, Daniel and Åsa Larsson.

Swedish Tax Agency (2018). Rättslig vägledning. Retrieved from https://www4.skatteverket.se/rattsligvagledning/edition/2018.7/325007.html

Waldenström, D. (2014). Swedish stock and bond returns, 1856-2012. In R. Edvinsson, T. Jacobson, \& D. Waldenström (Eds.), Historical monetary and financial statistics for Sweden: House prices, stock returns, national accounts and the Riksbank balance sheet, 1860-2012 (pp. 224-291). Stockholm: Sveriges Riksbank och Ekerlids Förlag.

Wykman, N. (2018). Swedish capital income taxation of owners of closely held corporations, 1991 to 2018. Mimeo: Örebro University. 


\section{Appendix A: Tax tables}

Table 1. Marginal tax rates.

\begin{tabular}{|c|c|c|c|c|c|}
\hline Year & $\begin{array}{c}\text { Corporate } \\
\operatorname{tax}\end{array}$ & $\begin{array}{l}\text { Interest } \\
\text { tax }\end{array}$ & $\begin{array}{l}\text { Dividends } \\
\qquad \operatorname{tax}\end{array}$ & $\begin{array}{c}\text { Capital } \\
\text { gains tax }\end{array}$ & $\begin{array}{c}\text { Wealth } \\
\text { tax }\end{array}$ \\
\hline 1862 & 3.0 & 3.0 & 0.0 & 0.0 & 0.0 \\
\hline 1863 & 3.0 & 3.0 & 0.0 & 0.0 & 0.0 \\
\hline 1864 & 3.0 & 3.0 & 0.0 & 0.0 & 0.0 \\
\hline 1865 & 3.0 & 3.0 & 0.0 & 0.0 & 0.0 \\
\hline 1866 & 3.0 & 3.0 & 0.0 & 0.0 & 0.0 \\
\hline 1867 & 3.0 & 3.0 & 0.0 & 0.0 & 0.0 \\
\hline 1868 & 3.0 & 3.0 & 0.0 & 0.0 & 0.0 \\
\hline 1869 & 3.0 & 3.0 & 0.0 & 0.0 & 0.0 \\
\hline 1870 & 3.0 & 3.0 & 0.0 & 0.0 & 0.0 \\
\hline 1871 & 3.5 & 3.5 & 0.0 & 0.0 & 0.0 \\
\hline 1872 & 3.0 & 3.0 & 0.0 & 0.0 & 0.0 \\
\hline 1873 & 3.0 & 3.0 & 0.0 & 0.0 & 0.0 \\
\hline 1874 & 3.0 & 3.0 & 0.0 & 0.0 & 0.0 \\
\hline 1875 & 3.2 & 3.2 & 0.0 & 0.0 & 0.0 \\
\hline 1876 & 3.5 & 3.5 & 0.0 & 0.0 & 0.0 \\
\hline 1877 & 3.6 & 3.6 & 0.0 & 0.0 & 0.0 \\
\hline 1878 & 4.0 & 4.0 & 0.0 & 0.0 & 0.0 \\
\hline 1879 & 4.8 & 4.8 & 0.0 & 0.0 & 0.0 \\
\hline 1880 & 5.3 & 5.3 & 0.0 & 0.0 & 0.0 \\
\hline 1881 & 5.4 & 5.4 & 0.0 & 0.0 & 0.0 \\
\hline 1882 & 5.6 & 5.6 & 0.0 & 0.0 & 0.0 \\
\hline 1883 & 5.2 & 5.2 & 0.0 & 0.0 & 0.0 \\
\hline 1884 & 5.3 & 5.3 & 0.0 & 0.0 & 0.0 \\
\hline 1885 & 5.5 & 5.5 & 0.0 & 0.0 & 0.0 \\
\hline 1886 & 5.9 & 5.9 & 0.0 & 0.0 & 0.0 \\
\hline
\end{tabular}




\begin{tabular}{|c|c|c|c|c|c|}
\hline Year & $\begin{array}{c}\text { Corporate } \\
\text { tax }\end{array}$ & $\begin{array}{c}\text { Interest } \\
\operatorname{tax}\end{array}$ & $\begin{array}{c}\text { Dividends } \\
\operatorname{tax}\end{array}$ & $\begin{array}{c}\text { Capital } \\
\text { gains tax }\end{array}$ & $\begin{array}{c}\text { Wealth } \\
\operatorname{tax}\end{array}$ \\
\hline 1887 & 5.9 & 5.9 & 0.0 & 0.0 & 0.0 \\
\hline 1888 & 5.8 & 5.8 & 0.0 & 0.0 & 0.0 \\
\hline 1889 & 5.7 & 5.7 & 0.0 & 0.0 & 0.0 \\
\hline 1890 & 5.6 & 5.6 & 0.0 & 0.0 & 0.0 \\
\hline 1891 & 5.6 & 5.6 & 0.0 & 0.0 & 0.0 \\
\hline 1892 & 5.7 & 5.7 & 0.0 & 0.0 & 0.0 \\
\hline 1893 & 6.1 & 6.1 & 0.0 & 0.0 & 0.0 \\
\hline 1894 & 6.9 & 6.9 & 0.0 & 0.0 & 0.0 \\
\hline 1895 & 6.8 & 6.8 & 0.0 & 0.0 & 0.0 \\
\hline 1896 & 6.0 & 6.0 & 0.0 & 0.0 & 0.0 \\
\hline 1897 & 5.6 & 5.6 & 0.0 & 0.0 & 0.0 \\
\hline 1898 & 5.5 & 5.5 & 0.0 & 0.0 & 0.0 \\
\hline 1899 & 5.3 & 5.3 & 0.0 & 0.0 & 0.0 \\
\hline 1900 & 5.4 & 5.4 & 0.0 & 0.0 & 0.0 \\
\hline 1901 & 6.8 & 6.8 & 0.0 & 0.0 & 0.0 \\
\hline 1902 & 7.0 & 7.0 & 0.0 & 0.0 & 0.0 \\
\hline 1903 & 11.2 & 11.2 & 5.0 & 0.0 & 0.0 \\
\hline 1904 & 11.2 & 11.2 & 5.0 & 0.0 & 0.0 \\
\hline 1905 & 11.4 & 11.4 & 5.0 & 0.0 & 0.0 \\
\hline 1906 & 11.4 & 11.4 & 5.0 & 0.0 & 0.0 \\
\hline 1907 & 11.4 & 11.4 & 5.0 & 0.0 & 0.0 \\
\hline 1908 & 12.2 & 12.2 & 5.0 & 0.0 & 0.0 \\
\hline 1909 & 12.8 & 12.8 & 5.0 & 0.0 & 0.0 \\
\hline 1910 & 12.3 & 12.3 & 5.0 & 0.0 & 0.0 \\
\hline 1911 & 11.3 & 12.2 & 6.0 & 0.0 & 0.1 \\
\hline 1912 & 11.4 & 12.3 & 6.0 & 0.0 & 0.1 \\
\hline 1913 & 11.3 & 25.7 & 19.5 & 0.0 & 1.5 \\
\hline
\end{tabular}




\begin{tabular}{|c|c|c|c|c|c|}
\hline Year & $\begin{array}{l}\text { Corporate } \\
\quad \operatorname{tax}\end{array}$ & $\begin{array}{c}\text { Interest } \\
\operatorname{tax}\end{array}$ & $\begin{array}{l}\text { Dividends } \\
\operatorname{tax}\end{array}$ & $\begin{array}{c}\text { Capital } \\
\text { gains tax }\end{array}$ & $\begin{array}{c}\text { Wealth } \\
\operatorname{tax}\end{array}$ \\
\hline$\overline{1914}$ & 11.6 & 12.5 & 6.0 & 0.0 & 0.1 \\
\hline 1915 & 12.4 & 13.3 & 6.0 & 0.0 & 0.1 \\
\hline 1916 & 11.7 & 12.6 & 6.0 & 0.0 & 0.1 \\
\hline 1917 & 11.4 & 12.3 & 6.0 & 0.0 & 0.1 \\
\hline 1918 & 17.0 & 29.9 & 23.0 & 0.0 & 0.4 \\
\hline 1919 & 22.4 & 30.3 & 23.0 & 0.0 & 0.4 \\
\hline 1920 & 31.3 & 33.3 & 33.3 & 0.0 & 0.5 \\
\hline 1921 & 31.8 & 36.4 & 36.4 & 0.0 & 0.5 \\
\hline 1922 & 31.9 & 36.5 & 36.5 & 0.0 & 0.5 \\
\hline 1923 & 32.0 & 36.6 & 36.6 & 0.0 & 0.5 \\
\hline 1924 & 32.3 & 36.9 & 36.9 & 0.0 & 0.5 \\
\hline 1925 & 32.3 & 36.2 & 36.2 & 0.0 & 0.5 \\
\hline 1926 & 32.3 & 35.0 & 35.0 & 0.0 & 0.5 \\
\hline 1927 & 32.3 & 35.1 & 35.1 & 0.0 & 0.5 \\
\hline 1928 & 32.2 & 33.8 & 33.8 & 0.0 & 0.5 \\
\hline 1929 & 32.1 & 32.9 & 32.9 & 0.0 & 0.5 \\
\hline 1930 & 32.4 & 33.1 & 33.1 & 0.0 & 0.5 \\
\hline 1931 & 33.5 & 34.5 & 34.5 & 0.0 & 0.5 \\
\hline 1932 & 34.1 & 38.5 & 38.5 & 0.0 & 0.5 \\
\hline 1933 & 33.7 & 40.7 & 40.7 & 0.0 & 0.6 \\
\hline 1934 & 34.3 & 42.2 & 42.2 & 0.0 & 1.1 \\
\hline 1935 & 34.0 & 42.0 & 42.0 & 0.0 & 1.1 \\
\hline 1936 & 34.0 & 45.4 & 45.4 & 0.0 & 1.2 \\
\hline 1937 & 34.0 & 45.4 & 45.4 & 0.0 & 1.2 \\
\hline 1938 & 37.8 & 47.3 & 47.3 & 0.0 & 1.2 \\
\hline 1939 & 29.5 & 59.0 & 59.0 & 0.0 & 1.1 \\
\hline 1940 & 39.5 & 65.4 & 65.4 & 0.0 & 1.2 \\
\hline
\end{tabular}




\begin{tabular}{|c|c|c|c|c|c|}
\hline Year & $\begin{array}{l}\text { Corporate } \\
\quad \operatorname{tax}\end{array}$ & $\begin{array}{c}\text { Interest } \\
\operatorname{tax}\end{array}$ & $\begin{array}{l}\text { Dividends } \\
\operatorname{tax}\end{array}$ & $\begin{array}{c}\text { Capital } \\
\text { gains tax }\end{array}$ & $\begin{array}{c}\text { Wealth } \\
\operatorname{tax}\end{array}$ \\
\hline$\overline{1941}$ & 38.9 & 65.1 & 65.1 & 0.0 & 1.2 \\
\hline 1942 & 40.4 & 72.0 & 72.0 & 0.0 & 1.3 \\
\hline 1943 & 40.1 & 71.9 & 71.9 & 0.0 & 1.3 \\
\hline 1944 & 40.1 & 71.9 & 71.9 & 0.0 & 1.3 \\
\hline 1945 & 40.0 & 71.9 & 71.9 & 0.0 & 1.3 \\
\hline 1946 & 40.0 & 71.9 & 71.9 & 0.0 & 1.3 \\
\hline 1947 & 39.8 & 71.8 & 71.8 & 0.0 & 1.3 \\
\hline 1948 & 45.9 & 72.9 & 72.9 & 0.0 & 1.8 \\
\hline 1949 & 46.1 & 73.0 & 73.0 & 0.0 & 1.8 \\
\hline 1950 & 46.0 & 73.0 & 73.0 & 0.0 & 1.8 \\
\hline 1951 & 46.1 & 73.1 & 73.1 & 0.0 & 1.8 \\
\hline 1952 & 47.5 & 73.8 & 73.8 & 0.0 & 1.8 \\
\hline 1953 & 47.6 & 69.5 & 69.5 & 0.0 & 1.8 \\
\hline 1954 & 47.4 & 69.3 & 69.3 & 0.0 & 1.8 \\
\hline 1955 & 51.7 & 69.3 & 69.3 & 0.0 & 1.8 \\
\hline 1956 & 56.2 & 69.3 & 69.3 & 0.0 & 1.8 \\
\hline 1957 & 56.3 & 69.4 & 69.4 & 0.0 & 1.8 \\
\hline 1958 & 56.8 & 69.8 & 69.8 & 0.0 & 1.8 \\
\hline 1959 & 57.1 & 70.0 & 70.0 & 0.0 & 1.8 \\
\hline 1960 & 48.8 & 70.1 & 70.1 & 0.0 & 1.8 \\
\hline 1961 & 49.0 & 70.3 & 70.3 & 0.0 & 1.8 \\
\hline 1962 & 49.1 & 70.3 & 70.3 & 0.0 & 1.8 \\
\hline 1963 & 49.3 & 70.4 & 70.4 & 0.0 & 1.8 \\
\hline 1964 & 49.9 & 70.8 & 70.8 & 0.0 & 1.8 \\
\hline 1965 & 50.4 & 71.0 & 71.0 & 0.0 & 1.8 \\
\hline 1966 & 51.0 & 71.4 & 71.4 & 17.9 & 1.8 \\
\hline 1967 & 51.2 & 71.5 & 71.5 & 17.9 & 1.8 \\
\hline
\end{tabular}




\begin{tabular}{|c|c|c|c|c|c|}
\hline Year & $\begin{array}{l}\text { Corporate } \\
\quad \operatorname{tax}\end{array}$ & $\begin{array}{c}\text { Interest } \\
\operatorname{tax}\end{array}$ & $\begin{array}{l}\text { Dividends } \\
\operatorname{tax}\end{array}$ & $\begin{array}{c}\text { Capital } \\
\text { gains tax }\end{array}$ & $\begin{array}{c}\text { Wealth } \\
\operatorname{tax}\end{array}$ \\
\hline 1968 & 51.6 & 71.8 & 71.8 & 17.9 & 1.8 \\
\hline 1969 & 52.1 & 72.1 & 72.1 & 18.0 & 1.8 \\
\hline 1970 & 52.6 & 72.4 & 72.4 & 18.1 & 1.8 \\
\hline 1971 & 53.5 & 76.5 & 76.5 & 19.1 & 2.5 \\
\hline 1972 & 54.3 & 77.8 & 77.8 & 19.4 & 2.5 \\
\hline 1973 & 54.4 & 77.9 & 77.9 & 19.5 & 2.5 \\
\hline 1974 & 54.4 & 78.0 & 78.0 & 19.5 & 2.5 \\
\hline 1975 & 55.1 & 81.2 & 81.2 & 20.3 & 2.5 \\
\hline 1976 & 55.7 & 83.2 & 83.2 & 33.3 & 2.5 \\
\hline 1977 & 56.1 & 84.9 & 84.9 & 33.9 & 2.5 \\
\hline 1978 & 57.2 & 86.7 & 86.7 & 34.7 & 2.5 \\
\hline 1979 & 57.4 & 87.0 & 87.0 & 34.8 & 2.5 \\
\hline 1980 & 57.5 & 85.0 & 85.0 & 34.0 & 2.5 \\
\hline 1981 & 57.7 & 85.0 & 85.0 & 34.0 & 2.5 \\
\hline 1982 & 57.8 & 85.0 & 85.0 & 34.0 & 2.5 \\
\hline 1983 & 58.1 & 84.0 & 84.0 & 33.6 & 4.0 \\
\hline 1984 & 62.2 & 82.0 & 82.0 & 32.8 & 3.0 \\
\hline 1985 & 57.1 & 80.0 & 80.0 & 32.0 & 3.0 \\
\hline 1986 & 57.1 & 80.3 & 80.3 & 32.1 & 3.0 \\
\hline 1987 & 57.1 & 77.4 & 77.4 & 31.0 & 3.0 \\
\hline 1988 & 57.1 & 75.6 & 75.6 & 30.2 & 3.0 \\
\hline 1989 & 54.7 & 72.8 & 72.8 & 29.1 & 3.0 \\
\hline 1990 & 47.8 & 66.2 & 66.2 & 26.5 & 3.0 \\
\hline 1991 & 30.0 & 30.0 & 30.0 & 30.0 & 2.5 \\
\hline 1992 & 30.0 & 30.0 & 25.0 & 25.0 & 1.5 \\
\hline 1993 & 30.0 & 30.0 & 25.0 & 25.0 & 1.5 \\
\hline 1994 & 28.0 & 30.0 & 0.0 & 12.5 & 1.5 \\
\hline
\end{tabular}




\begin{tabular}{|c|c|c|c|c|c|}
\hline Year & $\begin{array}{c}\text { Corporate } \\
\text { tax }\end{array}$ & $\begin{array}{c}\text { Interest } \\
\operatorname{tax}\end{array}$ & $\begin{array}{l}\text { Dividends } \\
\operatorname{tax}\end{array}$ & $\begin{array}{c}\text { Capital } \\
\text { gains tax }\end{array}$ & $\begin{array}{c}\text { Wealth } \\
\text { tax }\end{array}$ \\
\hline 1995 & 28.0 & 30.0 & 30.0 & 30.0 & 1.5 \\
\hline 1996 & 28.0 & 30.0 & 30.0 & 30.0 & 1.5 \\
\hline 1997 & 28.0 & 30.0 & 30.0 & 30.0 & 1.5 \\
\hline 1998 & 28.0 & 30.0 & 30.0 & 30.0 & 1.5 \\
\hline 1999 & 28.0 & 30.0 & 30.0 & 30.0 & 1.5 \\
\hline 2000 & 28.0 & 30.0 & 30.0 & 30.0 & 1.5 \\
\hline 2001 & 28.0 & 30.0 & 30.0 & 30.0 & 1.5 \\
\hline 2002 & 28.0 & 30.0 & 30.0 & 30.0 & 1.5 \\
\hline 2003 & 28.0 & 30.0 & 30.0 & 30.0 & 1.5 \\
\hline 2004 & 28.0 & 30.0 & 30.0 & 30.0 & 1.5 \\
\hline 2005 & 28.0 & 30.0 & 30.0 & 30.0 & 1.5 \\
\hline 2006 & 28.0 & 30.0 & 30.0 & 30.0 & 1.5 \\
\hline 2007 & 28.0 & 30.0 & 30.0 & 30.0 & 0.0 \\
\hline 2008 & 28.0 & 30.0 & 30.0 & 30.0 & 0.0 \\
\hline 2009 & 26.3 & 30.0 & 30.0 & 30.0 & 0.0 \\
\hline 2010 & 26.3 & 30.0 & 30.0 & 30.0 & 0.0 \\
\hline 2011 & 26.3 & 30.0 & 30.0 & 30.0 & 0.0 \\
\hline 2012 & 26.3 & 30.0 & 30.0 & 30.0 & 0.0 \\
\hline 2013 & 22.0 & 30.0 & 30.0 & 30.0 & 0.0 \\
\hline 2014 & 22.0 & 30.0 & 30.0 & 30.0 & 0.0 \\
\hline 2015 & 22.0 & 30.0 & 30.0 & 30.0 & 0.0 \\
\hline 2016 & 22.0 & 30.0 & 30.0 & 30.0 & 0.0 \\
\hline 2017 & 22.0 & 30.0 & 30.0 & 30.0 & 0.0 \\
\hline 2018 & 22.0 & 30.0 & 30.0 & 30.0 & 0.0 \\
\hline
\end{tabular}

Note: Interest rate, dividends rate, capital gains rate and wealth rate refer to the top marginal tax rates affecting an owner of a listed firm and are used to calculate the METR for the high-impact entrepreneur. Capital gains tax refers to long-term holdings (> 5 years) when applicable. 
Table 2. The marginal effective tax rate (METR), private foundations.

\begin{tabular}{|c|c|c|c|c|c|c|}
\hline Year & NSI & NSI* & Retained earnings & Debt & Debt* & Mix \\
\hline 1862 & 1.8 & 102.3 & 1.8 & -2.1 & 101.5 & 1.8 \\
\hline 1863 & 0.9 & 40.3 & 0.9 & -0.7 & 40.0 & 0.9 \\
\hline 1864 & 1.0 & 46.0 & 1.0 & -0.8 & 45.7 & 1.0 \\
\hline 1865 & 1.5 & 79.3 & 1.5 & -1.5 & 78.7 & 1.5 \\
\hline 1866 & 1.9 & 105.9 & 1.9 & -2.2 & 105.1 & 1.9 \\
\hline 1867 & 2.1 & 130.9 & 2.1 & -2.8 & 129.9 & 2.1 \\
\hline 1868 & 1.9 & 107.4 & 1.9 & -2.2 & 106.6 & 1.9 \\
\hline 1869 & 0.8 & 34.2 & 0.8 & -0.5 & 33.9 & 0.8 \\
\hline 1870 & 1.0 & 46.7 & 1.0 & -0.8 & 46.4 & 1.0 \\
\hline 1871 & 2.1 & 101.4 & 2.1 & -2.4 & 100.5 & 2.1 \\
\hline 1872 & 1.9 & 112.5 & 1.9 & -2.3 & 111.6 & 1.9 \\
\hline 1873 & 2.3 & 144.0 & 2.3 & -3.2 & 142.9 & 2.3 \\
\hline 1874 & 1.9 & 108.9 & 1.9 & -2.2 & 108.1 & 1.9 \\
\hline 1875 & 1.5 & 75.3 & 1.5 & -1.5 & 74.7 & 1.5 \\
\hline 1876 & 1.8 & 82.9 & 1.8 & -1.9 & 82.2 & 1.8 \\
\hline 1877 & 1.8 & 76.2 & 1.8 & -1.7 & 75.5 & 1.8 \\
\hline 1878 & 0.9 & 27.9 & 0.9 & -0.6 & 27.6 & 0.9 \\
\hline 1879 & 1.1 & 30.6 & 1.1 & -0.8 & 30.2 & 1.1 \\
\hline 1880 & 3.6 & 122.1 & 3.6 & -4.6 & 120.4 & 3.6 \\
\hline 1881 & 3.3 & 100.8 & 3.3 & -3.7 & 99.4 & 3.3 \\
\hline 1882 & 2.3 & 59.0 & 2.3 & -2.0 & 58.2 & 2.3 \\
\hline 1883 & 2.5 & 75.9 & 2.5 & -2.5 & 74.9 & 2.5 \\
\hline 1884 & 1.9 & 50.9 & 1.9 & -1.6 & 50.2 & 1.9 \\
\hline 1885 & 1.7 & 43.0 & 1.7 & -1.3 & 42.4 & 1.7 \\
\hline 1886 & 1.7 & 41.2 & 1.7 & -1.3 & 40.6 & 1.7 \\
\hline 1887 & 2.1 & 51.9 & 2.1 & -1.8 & 51.2 & 2.1 \\
\hline 1888 & 3.7 & 109.2 & 3.7 & -4.4 & 107.6 & 3.7 \\
\hline
\end{tabular}




\begin{tabular}{|c|c|c|c|c|c|c|}
\hline Year & NSI & NSI* & Retained earnings & Debt & Debt* & Mix \\
\hline 1889 & 3.8 & 116.7 & 3.8 & -4.7 & 115.0 & 3.8 \\
\hline 1890 & 3.3 & 97.9 & 3.3 & -3.7 & 96.4 & 3.3 \\
\hline 1891 & 3.5 & 105.4 & 3.5 & -4.1 & 103.9 & 3.5 \\
\hline 1892 & 2.5 & 66.1 & 2.5 & -2.3 & 65.1 & 2.5 \\
\hline 1893 & 2.1 & 48.1 & 2.1 & -1.7 & 47.4 & 2.1 \\
\hline 1894 & 2.0 & 39.6 & 2.0 & -1.5 & 38.9 & 2.0 \\
\hline 1895 & 4.0 & 95.8 & 4.0 & -4.4 & 94.1 & 4.0 \\
\hline 1896 & 2.9 & 74.3 & 2.9 & -2.8 & 73.1 & 2.9 \\
\hline 1897 & 3.5 & 106.2 & 3.5 & -4.1 & 104.7 & 3.5 \\
\hline 1898 & 3.7 & 118.8 & 3.7 & -4.6 & 117.2 & 3.7 \\
\hline 1899 & 3.5 & 116.1 & 3.5 & -4.4 & 114.5 & 3.5 \\
\hline 1900 & 3.0 & 90.0 & 3.0 & -3.2 & 88.8 & 3.0 \\
\hline 1901 & 2.8 & 61.0 & 2.8 & -2.5 & 60.0 & 2.8 \\
\hline 1902 & 3.8 & 87.4 & 3.8 & -4.1 & 85.9 & 3.8 \\
\hline 1903 & 6.5 & 94.5 & 6.5 & -7.3 & 91.8 & 8.7 \\
\hline 1904 & 5.3 & 71.8 & 5.3 & -5.2 & 69.7 & 7.0 \\
\hline 1905 & 6.8 & 98.3 & 6.8 & -7.8 & 95.4 & 9.1 \\
\hline 1906 & 6.8 & 98.0 & 6.8 & -7.8 & 95.0 & 9.1 \\
\hline 1907 & 8.0 & 123.1 & 8.0 & -10.5 & 119.4 & 10.9 \\
\hline 1908 & 7.1 & 93.4 & 7.1 & -7.9 & 90.4 & 9.3 \\
\hline 1909 & 6.2 & 73.6 & 6.2 & -6.1 & 71.2 & 7.9 \\
\hline 1910 & 6.5 & 81.3 & 6.5 & -6.7 & 78.7 & 8.3 \\
\hline 1911 & 7.2 & 105.3 & 7.2 & -8.5 & 102.2 & 11.1 \\
\hline 1912 & 6.8 & 97.9 & 6.8 & -7.8 & 95.0 & 10.6 \\
\hline 1913 & 6.0 & 83.6 & 6.0 & -6.3 & 81.2 & 28.1 \\
\hline 1914 & 6.6 & 91.9 & 6.6 & -7.3 & 89.1 & 10.2 \\
\hline 1915 & 11.7 & 201.4 & 11.7 & -21.7 & 194.7 & 18.4 \\
\hline 1916 & 10.6 & 186.5 & 10.6 & -18.4 & 180.7 & 16.9 \\
\hline
\end{tabular}




\begin{tabular}{|c|c|c|c|c|c|c|}
\hline Year & NSI & NSI* & Retained earnings & Debt & Debt* & Mix \\
\hline 1917 & 12.9 & 291.8 & 12.9 & -31.9 & 282.9 & 22.3 \\
\hline 1918 & 23.4 & 460.3 & 23.4 & -88.7 & 437.9 & 77.5 \\
\hline 1919 & 19.8 & 166.9 & 19.8 & -33.3 & 156.3 & 40.5 \\
\hline 1920 & 20.3 & 99.1 & 20.3 & -24.7 & 90.1 & 38.2 \\
\hline 1921 & -25.7 & -57.5 & -25.7 & 1.8 & -67.2 & -29.0 \\
\hline 1922 & -19.5 & -57.8 & -19.5 & 2.9 & -53.4 & -21.2 \\
\hline 1923 & 9.6 & 38.4 & 9.6 & -7.4 & 35.0 & 20.2 \\
\hline 1924 & 18.5 & 83.7 & 18.5 & -20.4 & 75.9 & 35.8 \\
\hline 1925 & 20.8 & 98.0 & 20.8 & -25.2 & 88.7 & 40.0 \\
\hline 1926 & 13.3 & 55.6 & 13.3 & -11.9 & 50.5 & 25.7 \\
\hline 1927 & 16.8 & 74.0 & 16.8 & -17.3 & 67.2 & 31.8 \\
\hline 1928 & 20.0 & 93.5 & 20.0 & -23.6 & 84.8 & 37.1 \\
\hline 1929 & 15.8 & 69.1 & 15.8 & -15.7 & 62.8 & 29.2 \\
\hline 1930 & 13.0 & 54.0 & 13.0 & -11.5 & 49.1 & 24.4 \\
\hline 1931 & 14.4 & 58.2 & 14.4 & -13.1 & 52.7 & 26.6 \\
\hline 1932 & 17.8 & 73.4 & 17.8 & -18.2 & 66.2 & 33.7 \\
\hline 1933 & 15.4 & 62.4 & 15.4 & -14.5 & 56.4 & 30.8 \\
\hline 1934 & 20.8 & 89.5 & 20.8 & -24.0 & 80.5 & 46.4 \\
\hline 1935 & 22.4 & 100.3 & 22.4 & -27.7 & 90.2 & 49.9 \\
\hline 1936 & 21.5 & 94.6 & 21.5 & -25.6 & 85.2 & 49.9 \\
\hline 1937 & 24.0 & 110.3 & 24.0 & -31.6 & 99.2 & 55.4 \\
\hline 1938 & 25.2 & 99.8 & 25.2 & -31.5 & 88.5 & 54.9 \\
\hline 1939 & 4.9 & 105.0 & 4.9 & -47.5 & 94.5 & 45.8 \\
\hline 1940 & 12.7 & 190.8 & 12.7 & -132.7 & 161.7 & 83.0 \\
\hline 1941 & 12.3 & 190.2 & 12.3 & -129.1 & 162.0 & 82.3 \\
\hline 1942 & 9.7 & 136.7 & 9.7 & -98.0 & 115.2 & 68.4 \\
\hline 1943 & 6.2 & 84.7 & 6.2 & -59.6 & 71.5 & 47.3 \\
\hline 1944 & 5.7 & 77.7 & 5.7 & -54.5 & 65.7 & 44.5 \\
\hline
\end{tabular}




\begin{tabular}{|c|c|c|c|c|c|c|}
\hline Year & NSI & NSI* & Retained earnings & Debt & Debt* & Mix \\
\hline 1945 & 5.7 & 77.7 & 5.7 & -54.4 & 65.7 & 44.4 \\
\hline 1946 & 6.1 & 84.7 & 6.1 & -59.3 & 71.6 & 47.2 \\
\hline 1947 & 7.5 & 105.4 & 7.5 & -73.6 & 89.2 & 55.5 \\
\hline 1948 & 11.2 & 128.7 & 11.2 & -113.4 & 103.8 & 72.1 \\
\hline 1949 & 7.7 & 84.7 & 7.7 & -74.6 & 68.2 & 53.8 \\
\hline 1950 & 8.4 & 94.2 & 8.4 & -82.8 & 75.9 & 57.7 \\
\hline 1951 & 18.0 & 219.0 & 18.0 & -197.0 & 176.0 & 109.4 \\
\hline 1952 & 42.9 & 146.5 & 42.9 & -74.3 & 123.0 & 99.1 \\
\hline 1953 & 30.9 & 91.1 & 30.9 & -37.6 & 77.4 & 69.8 \\
\hline 1954 & 30.7 & 91.0 & 30.7 & -37.4 & 77.4 & 69.6 \\
\hline 1955 & 27.6 & 107.3 & 27.6 & -36.3 & 94.6 & 73.2 \\
\hline 1956 & 34.1 & 126.9 & 34.1 & -51.4 & 109.8 & 84.3 \\
\hline 1957 & 33.4 & 122.6 & 33.4 & -49.1 & 106.1 & 82.4 \\
\hline 1958 & 33.5 & 121.1 & 33.5 & -48.9 & 104.6 & 82.1 \\
\hline 1959 & 27.6 & 91.7 & 27.6 & -33.2 & 79.5 & 68.0 \\
\hline 1960 & 27.6 & 118.2 & 27.6 & -38.5 & 105.0 & 77.4 \\
\hline 1961 & 12.0 & 100.1 & 25.1 & -31.9 & 91.3 & 68.8 \\
\hline 1962 & 16.7 & 121.8 & 28.7 & -41.6 & 110.1 & 78.9 \\
\hline 1963 & 13.5 & 106.6 & 26.4 & -34.9 & 96.9 & 72.0 \\
\hline 1964 & 14.0 & 107.7 & 27.0 & -36.0 & 97.7 & 73.0 \\
\hline 1965 & 17.9 & 125.0 & 30.1 & -44.6 & 112.6 & 81.3 \\
\hline 1966 & 20.6 & 136.7 & 32.3 & -51.2 & 122.3 & 94.2 \\
\hline 1967 & 7.4 & 113.8 & 29.2 & -41.0 & 104.2 & 82.5 \\
\hline 1968 & 2.5 & 96.8 & 26.4 & -33.5 & 89.6 & 73.8 \\
\hline 1969 & -0.4 & 87.2 & 24.9 & -29.7 & 81.3 & 68.9 \\
\hline 1970 & 17.9 & 154.1 & 36.3 & -63.8 & 137.7 & 104.4 \\
\hline 1971 & 11.4 & 141.5 & 27.7 & -44.1 & 130.4 & 104.4 \\
\hline 1972 & 9.2 & 129.8 & 26.7 & -40.1 & 120.0 & 99.4 \\
\hline
\end{tabular}




\begin{tabular}{|c|c|c|c|c|c|c|}
\hline Year & NSI & NSI* & Retained earnings & Debt & Debt* & Mix \\
\hline 1973 & 10.5 & 135.7 & 27.5 & -42.6 & 125.1 & 102.6 \\
\hline 1974 & 15.5 & 162.3 & 30.6 & -54.1 & 148.4 & 116.7 \\
\hline 1975 & 15.6 & 161.5 & 31.0 & -54.7 & 147.5 & 119.3 \\
\hline 1976 & -5.3 & 161.3 & 12.1 & -87.4 & 144.9 & 118.4 \\
\hline 1977 & -3.5 & 169.7 & 13.4 & -91.7 & 152.1 & 125.5 \\
\hline 1978 & -5.2 & 159.8 & 12.8 & -89.3 & 142.9 & 121.7 \\
\hline 1979 & 12.1 & 140.0 & 29.9 & -47.7 & 128.1 & 118.3 \\
\hline 1980 & -2.3 & 189.1 & 14.0 & -107.9 & 168.0 & 136.6 \\
\hline 1981 & 8.7 & 178.5 & 43.1 & -88.1 & 159.2 & 144.7 \\
\hline 1982 & 0.2 & 148.8 & 39.1 & -69.5 & 134.9 & 126.7 \\
\hline 1983 & 1.1 & 151.4 & 39.7 & -71.6 & 136.9 & 142.4 \\
\hline 1984 & -0.9 & 143.8 & 41.9 & -74.3 & 129.1 & 127.7 \\
\hline 1985 & -2.7 & 139.5 & 37.1 & -62.6 & 127.5 & 121.3 \\
\hline 1986 & -12.3 & 111.1 & 32.4 & -46.8 & 104.2 & 104.7 \\
\hline 1987 & -12.3 & 111.1 & 32.4 & -46.8 & 104.2 & 102.5 \\
\hline 1988 & -6.6 & 127.5 & 35.2 & -55.8 & 117.6 & 110.5 \\
\hline 1989 & -5.2 & 131.8 & 34.1 & -54.6 & 121.9 & 109.7 \\
\hline 1990 & 2.9 & 163.8 & 32.9 & -59.8 & 151.2 & 117.7 \\
\hline 1991 & -3.4 & 153.7 & 23.5 & -49.2 & 144.6 & 76.5 \\
\hline 1992 & -18.3 & 94.7 & 16.1 & -29.8 & 92.4 & 39.8 \\
\hline 1993 & -12.7 & 115.1 & 18.9 & -36.0 & 110.4 & 47.2 \\
\hline 1994 & 16.2 & 100.8 & 16.2 & -19.5 & 93.7 & 35.1 \\
\hline 1995 & 16.4 & 103.3 & 16.4 & -20.1 & 96.0 & 54.2 \\
\hline 1996 & 14.5 & 86.9 & 14.5 & -16.0 & 80.8 & 48.5 \\
\hline 1997 & 14.5 & 86.9 & 14.5 & -16.0 & 80.8 & 48.5 \\
\hline 1998 & 13.8 & 81.2 & 13.8 & -14.6 & 75.5 & 46.4 \\
\hline 1999 & 14.5 & 86.9 & 14.5 & -16.0 & 80.8 & 48.5 \\
\hline 2000 & 15.0 & 91.0 & 15.0 & -17.0 & 84.6 & 49.9 \\
\hline
\end{tabular}




\begin{tabular}{lllllll}
\hline Year & NSI & NSI* & Retained earnings & Debt & Debt* & Mix \\
\cline { 2 - 5 } 2001 & 16.3 & 102.5 & 16.3 & -19.9 & 95.2 & 53.9 \\
2002 & 16.2 & 100.8 & 16.2 & -19.5 & 93.7 & 53.4 \\
2003 & 15.9 & 98.4 & 15.9 & -18.9 & 91.4 & 52.5 \\
2004 & 14.4 & 86.1 & 14.4 & -15.8 & 80.0 & 48.2 \\
2005 & 14.5 & 86.9 & 14.5 & -16.0 & 80.8 & 48.5 \\
2006 & 15.4 & 94.3 & 15.4 & -17.8 & 87.6 & 51.1 \\
2007 & 16.2 & 100.8 & 16.2 & -19.5 & 93.7 & 38.4 \\
2008 & 17.2 & 110.6 & 17.2 & -22.1 & 102.8 & 41.8 \\
2009 & 12.7 & 80.1 & 12.7 & -13.4 & 74.9 & 30.4 \\
2010 & 14.3 & 93.3 & 14.3 & -16.4 & 87.1 & 35.0 \\
2011 & 15.4 & 103.9 & 15.4 & -18.9 & 97.0 & 38.6 \\
2012 & 13.9 & 90.0 & 13.9 & -15.6 & 84.1 & 33.9 \\
2013 & 10.7 & 82.1 & 10.7 & -11.3 & 77.7 & 29.5 \\
2014 & 10.6 & 80.5 & 10.6 & -11.0 & 76.2 & 28.9 \\
2015 & 10.7 & 82.1 & 10.7 & -11.3 & 77.7 & 29.5 \\
2016 & 11.5 & 90.3 & 11.5 & -12.8 & 85.4 & 32.2 \\
2017 & 12.1 & 96.8 & 12.1 & -14.0 & 91.6 & 34.3 \\
2018 & 12.1 & 96.8 & 12.1 & -14.0 & 91.6 & 34.3 \\
\hline & 1.9 & & & & \\
\hline
\end{tabular}

Note: NSI* and Debt* refer to the METR, including the cash flow effect, i.e., including the requirement to donate 80 percent of the return to charitable purposes.

Mixed strategy refers to the case in which 60 percent of the return is taxed as capital gains and 40 percent as dividends. 
Table 3. The marginal effective tax rate (METR), entrepreneurs.

\begin{tabular}{|c|c|c|c|c|}
\hline Year & NSI & Retained earnings & Debt & Mix \\
\hline 1862 & 1.8 & 1.8 & 1.8 & 1.8 \\
\hline 1863 & 0.9 & 0.9 & 0.9 & 0.9 \\
\hline 1864 & 1.0 & 1.0 & 1.0 & 1.0 \\
\hline 1865 & 1.5 & 1.5 & 1.5 & 1.5 \\
\hline 1866 & 1.9 & 1.9 & 1.9 & 1.9 \\
\hline 1867 & 2.1 & 2.1 & 2.1 & 2.1 \\
\hline 1868 & 1.9 & 1.9 & 1.9 & 1.9 \\
\hline 1869 & 0.8 & 0.8 & 0.8 & 0.8 \\
\hline 1870 & 1.0 & 1.0 & 1.0 & 1.0 \\
\hline 1871 & 2.1 & 2.1 & 2.1 & 2.1 \\
\hline 1872 & 1.9 & 1.9 & 1.9 & 1.9 \\
\hline 1873 & 2.3 & 2.3 & 2.3 & 2.3 \\
\hline 1874 & 1.9 & 1.9 & 1.9 & 1.9 \\
\hline 1875 & 1.5 & 1.5 & 1.5 & 1.5 \\
\hline 1876 & 1.8 & 1.8 & 1.8 & 1.8 \\
\hline 1877 & 1.8 & 1.8 & 1.8 & 1.8 \\
\hline 1878 & 0.9 & 0.9 & 0.9 & 0.9 \\
\hline 1879 & 1.1 & 1.1 & 1.1 & 1.1 \\
\hline 1880 & 3.6 & 3.6 & 3.6 & 3.6 \\
\hline 1881 & 3.3 & 3.3 & 3.3 & 3.3 \\
\hline 1882 & 2.3 & 2.3 & 2.3 & 2.3 \\
\hline 1883 & 2.5 & 2.5 & 2.5 & 2.5 \\
\hline 1884 & 1.9 & 1.9 & 1.9 & 1.9 \\
\hline 1885 & 1.7 & 1.7 & 1.7 & 1.7 \\
\hline 1886 & 1.7 & 1.7 & 1.7 & 1.7 \\
\hline 1887 & 2.1 & 2.1 & 2.1 & 2.1 \\
\hline 1888 & 3.7 & 3.7 & 3.7 & 3.7 \\
\hline
\end{tabular}




\begin{tabular}{|c|c|c|c|c|}
\hline Year & NSI & Retained earnings & Debt & Mix \\
\hline 1889 & 3.8 & 3.8 & 3.8 & 3.8 \\
\hline 1890 & 3.3 & 3.3 & 3.3 & 3.3 \\
\hline 1891 & 3.5 & 3.5 & 3.5 & 3.5 \\
\hline 1892 & 2.5 & 2.5 & 2.5 & 2.5 \\
\hline 1893 & 2.1 & 2.1 & 2.1 & 2.1 \\
\hline 1894 & 2.0 & 2.0 & 2.0 & 2.0 \\
\hline 1895 & 4.0 & 4.0 & 4.0 & 4.0 \\
\hline 1896 & 2.9 & 2.9 & 2.9 & 2.9 \\
\hline 1897 & 3.5 & 3.5 & 3.5 & 3.5 \\
\hline 1898 & 3.7 & 3.7 & 3.7 & 3.7 \\
\hline 1899 & 3.5 & 3.5 & 3.5 & 3.5 \\
\hline 1900 & 3.0 & 3.0 & 3.0 & 3.0 \\
\hline 1901 & 2.8 & 2.8 & 2.8 & 2.8 \\
\hline 1902 & 3.8 & 3.8 & 3.8 & 3.8 \\
\hline 1903 & 12.0 & 6.5 & 6.5 & 8.7 \\
\hline 1904 & 9.5 & 5.3 & 5.3 & 7.0 \\
\hline 1905 & 12.6 & 6.8 & 6.8 & 9.1 \\
\hline 1906 & 12.5 & 6.8 & 6.8 & 9.1 \\
\hline 1907 & 15.2 & 8.0 & 8.0 & 10.9 \\
\hline 1908 & 12.5 & 7.1 & 7.1 & 9.3 \\
\hline 1909 & 10.5 & 6.2 & 6.2 & 7.9 \\
\hline 1910 & 11.2 & 6.5 & 6.5 & 8.3 \\
\hline 1911 & 15.5 & 8.2 & 9.4 & 11.1 \\
\hline 1912 & 14.7 & 7.8 & 9.0 & 10.6 \\
\hline 1913 & 39.4 & 20.5 & 36.3 & 28.1 \\
\hline 1914 & 14.0 & 7.6 & 8.7 & 10.2 \\
\hline 1915 & 26.9 & 12.7 & 15.1 & 18.4 \\
\hline 1916 & 24.8 & 11.6 & 13.8 & 16.9 \\
\hline
\end{tabular}




\begin{tabular}{|c|c|c|c|c|}
\hline Year & NSI & Retained earnings & Debt & Mix \\
\hline 1917 & 34.8 & 13.9 & 17.5 & 22.3 \\
\hline 1918 & 152.8 & 27.2 & 112.1 & 77.5 \\
\hline 1919 & 65.9 & 23.6 & 42.3 & 40.5 \\
\hline 1920 & 57.8 & 25.1 & 27.9 & 38.2 \\
\hline 1921 & -41.8 & -20.4 & -24.3 & -29.0 \\
\hline 1922 & -31.7 & -14.2 & -17.4 & -21.2 \\
\hline 1923 & 28.1 & 14.9 & 17.4 & 20.2 \\
\hline 1924 & 53.9 & 23.8 & 29.3 & 35.8 \\
\hline 1925 & 61.0 & 26.0 & 31.6 & 40.0 \\
\hline 1926 & 36.7 & 18.3 & 20.3 & 25.7 \\
\hline 1927 & 46.9 & 21.8 & 24.7 & 31.8 \\
\hline 1928 & 55.8 & 24.7 & 26.9 & 37.1 \\
\hline 1929 & 42.3 & 20.4 & 21.2 & 29.2 \\
\hline 1930 & 34.6 & 17.6 & 18.2 & 24.4 \\
\hline 1931 & 37.9 & 19.0 & 19.9 & 26.6 \\
\hline 1932 & 49.8 & 23.0 & 27.7 & 33.7 \\
\hline 1933 & 45.1 & 21.2 & 27.4 & 30.8 \\
\hline 1934 & 68.2 & 31.9 & 42.3 & 46.4 \\
\hline 1935 & 74.4 & 33.6 & 45.4 & 49.9 \\
\hline 1936 & 74.9 & 33.3 & 49.2 & 49.9 \\
\hline 1937 & 84.8 & 35.8 & 54.5 & 55.4 \\
\hline 1938 & 81.4 & 37.3 & 51.6 & 54.9 \\
\hline 1939 & 90.1 & 16.3 & 68.7 & 45.8 \\
\hline 1940 & 170.4 & 24.7 & 120.1 & 83.0 \\
\hline 1941 & 169.2 & 24.4 & 119.8 & 82.3 \\
\hline 1942 & 137.0 & 22.6 & 106.9 & 68.4 \\
\hline 1943 & 89.6 & 19.0 & 71.1 & 47.3 \\
\hline 1944 & 83.3 & 18.6 & 66.4 & 44.5 \\
\hline
\end{tabular}




\begin{tabular}{|c|c|c|c|c|}
\hline Year & NSI & Retained earnings & Debt & Mix \\
\hline 1945 & 83.3 & 18.5 & 66.4 & 44.4 \\
\hline 1946 & 89.6 & 19.0 & 71.2 & 47.2 \\
\hline 1947 & 108.3 & 20.4 & 85.4 & 55.5 \\
\hline 1948 & 136.4 & 29.2 & 102.6 & 72.1 \\
\hline 1949 & 96.0 & 25.7 & 73.8 & 53.8 \\
\hline 1950 & 104.7 & 26.4 & 80.0 & 57.7 \\
\hline 1951 & 219.5 & 36.0 & 161.6 & 109.4 \\
\hline 1952 & 156.4 & 60.9 & 125.6 & 99.1 \\
\hline 1953 & 101.1 & 48.9 & 80.2 & 69.8 \\
\hline 1954 & 101.0 & 48.7 & 80.1 & 69.6 \\
\hline 1955 & 114.6 & 45.6 & 95.0 & 73.2 \\
\hline 1956 & 132.5 & 52.1 & 106.3 & 84.3 \\
\hline 1957 & 128.8 & 51.4 & 103.6 & 82.4 \\
\hline 1958 & 127.9 & 51.5 & 103.0 & 82.1 \\
\hline 1959 & 101.7 & 45.6 & 83.4 & 68.0 \\
\hline 1960 & 125.1 & 45.6 & 105.3 & 77.4 \\
\hline 1961 & 107.3 & 43.1 & 94.3 & 68.8 \\
\hline 1962 & 127.1 & 46.7 & 109.8 & 78.9 \\
\hline 1963 & 113.4 & 44.4 & 99.1 & 72.0 \\
\hline 1964 & 114.9 & 45.0 & 100.3 & 73.0 \\
\hline 1965 & 131.0 & 48.1 & 112.9 & 81.3 \\
\hline 1966 & 142.2 & 62.2 & 121.7 & 94.2 \\
\hline 1967 & 120.6 & 57.1 & 106.8 & 82.5 \\
\hline 1968 & 105.1 & 52.9 & 94.9 & 73.8 \\
\hline 1969 & 96.5 & 50.5 & 88.3 & 68.9 \\
\hline 1970 & 159.1 & 68.0 & 136.5 & 104.4 \\
\hline 1971 & 160.9 & 66.7 & 147.8 & 104.4 \\
\hline 1972 & 151.5 & 64.7 & 140.6 & 99.4 \\
\hline
\end{tabular}




\begin{tabular}{|c|c|c|c|c|}
\hline Year & NSI & Retained earnings & Debt & Mix \\
\hline 1973 & 157.5 & 66.1 & 145.8 & 102.6 \\
\hline 1974 & 183.7 & 72.0 & 168.4 & 116.7 \\
\hline 1975 & 188.8 & 73.0 & 175.6 & 119.3 \\
\hline 1976 & 192.9 & 68.8 & 179.1 & 118.4 \\
\hline 1977 & 205.2 & 72.3 & 191.8 & 125.5 \\
\hline 1978 & 198.6 & 70.5 & 187.4 & 121.7 \\
\hline 1979 & 176.2 & 79.6 & 168.5 & 118.3 \\
\hline 1980 & 226.1 & 76.9 & 210.3 & 136.6 \\
\hline 1981 & 214.2 & 98.3 & 199.6 & 144.7 \\
\hline 1982 & 183.1 & 89.1 & 172.7 & 126.7 \\
\hline 1983 & 198.9 & 104.8 & 187.3 & 142.4 \\
\hline 1984 & 177.4 & 94.6 & 164.2 & 127.7 \\
\hline 1985 & 169.5 & 89.2 & 157.5 & 121.3 \\
\hline 1986 & 141.7 & 80.0 & 134.9 & 104.7 \\
\hline 1987 & 137.2 & 79.4 & 129.4 & 102.5 \\
\hline 1988 & 150.0 & 84.2 & 138.0 & 110.5 \\
\hline 1989 & 149.4 & 83.3 & 136.0 & 109.7 \\
\hline 1990 & 165.9 & 85.5 & 144.7 & 117.7 \\
\hline 1991 & 80.5 & 73.9 & 48.5 & 76.5 \\
\hline 1992 & 32.9 & 44.4 & 31.1 & 39.8 \\
\hline 1993 & 43.1 & 49.9 & 33.9 & 47.2 \\
\hline 1994 & 31.2 & 37.8 & 37.9 & 35.1 \\
\hline 1995 & 64.0 & 47.7 & 38.4 & 54.2 \\
\hline 1996 & 56.6 & 43.1 & 35.3 & 48.5 \\
\hline 1997 & 56.6 & 43.1 & 35.3 & 48.5 \\
\hline 1998 & 54.0 & 41.4 & 34.2 & 46.4 \\
\hline 1999 & 56.6 & 43.1 & 35.3 & 48.5 \\
\hline 2000 & 58.5 & 44.2 & 36.1 & 49.9 \\
\hline
\end{tabular}




\begin{tabular}{|c|c|c|c|c|}
\hline Year & NSI & Retained earnings & Debt & Mix \\
\hline 2001 & 63.6 & 47.5 & 38.2 & 53.9 \\
\hline 2002 & 62.9 & 47.0 & 37.9 & 53.4 \\
\hline 2003 & 61.8 & 46.3 & 37.5 & 52.5 \\
\hline 2004 & 56.3 & 42.8 & 35.1 & 48.2 \\
\hline 2005 & 56.6 & 43.1 & 35.3 & 48.5 \\
\hline 2006 & 60.0 & 45.2 & 36.7 & 51.1 \\
\hline 2007 & 47.9 & 32.0 & 22.9 & 38.4 \\
\hline 2008 & 52.3 & 34.8 & 24.7 & 41.8 \\
\hline 2009 & 38.0 & 25.4 & 19.7 & 30.4 \\
\hline 2010 & 43.9 & 29.1 & 22.5 & 35.0 \\
\hline 2011 & 48.6 & 32.0 & 24.6 & 38.6 \\
\hline 2012 & 42.4 & 28.2 & 21.8 & 33.9 \\
\hline 2013 & 37.5 & 24.1 & 22.1 & 29.5 \\
\hline 2014 & 36.8 & 23.7 & 21.7 & 28.9 \\
\hline 2015 & 37.5 & 24.1 & 22.1 & 29.5 \\
\hline 2016 & 41.1 & 26.3 & 24.0 & 32.2 \\
\hline 2017 & 43.9 & 28.0 & 25.6 & 34.3 \\
\hline 2018 & 43.9 & 28.0 & 25.6 & 34.3 \\
\hline
\end{tabular}

Note: Entrepreneur refers to an owner of a listed firm paying the highest marginal income tax. Mixed strategy refers to the case in which 60 percent of the return is taxed as capital gains and 40 percent as dividends. 


\section{Appendix B: Private foundations and family control - a detailed description}

This appendix portrays the private foundations in Sweden in more detail. The government inquiry SOU 1968:7, the so-called concentration's inquiry (Koncentrationsutredningen), with the purpose of investigating ownership and influence in private industry, is a standard source of information. ${ }^{39}$ In total, 17 ownership spheres that controlled one-third of the largest firms' capital in the early 1960s were identified in the inquiry. In combination with differentiated voting rights and so-called 'pyramidbuilding', several companies could be controlled with a relatively small amount of capital (Hagstedt, 1972). Their influence was therefore greater than what can be inferred from the percentage ownership of the total capital. In total, these ownership spheres controlled firms representing approximately one-fifth of total private employment, excluding banks and insurance companies. ${ }^{40}$

Fourteen of the spheres were family groups (identified group members in parentheses):

1. Wallenberg (Jacob Wallenberg, 1892-1980, Marcus Wallenberg, 1899-1982, and the latter's children $)^{41}$,

2. Wehtje (descendant of Ernst Wehtje, 1863-1936, and their spouses),

\footnotetext{
${ }^{39}$ It was a comprehensive inquiry directed by Guy Arvidsson, professor of economics. Among other things, four Ph.D. theses were based on the inquiry (Persson-Tanimura, 1988).

Hermansson (1959) was one 'source of inspiration' for the inquiry. Hermansson later became the leader of the Communist Party (Sveriges kommunistiska parti, SKP).

${ }^{40}$ Total employment in private Swedish industry was reported to amount to 1983606 people (SOU 1968:7, Table 2.2., p. 48), and the Swedish employment in firms controlled by the spheres was reported to be 402400 people (SOU 1968:7, Table 4.18, p. 154). Foreign employment is excluded in the reported numbers. The Wallenberg sphere was the largest, controlling firms employing approximately 150000 persons in Sweden, followed by Industrivärden/Handelsbanken and Custos/Säfveån-Skandinaviska Banken, controlling firms employing approximately 60000 people in Sweden.

${ }^{41}$ Jacob and Marcus were sons of Marcus Wallenberg sr, 1864-1943, who controlled Knut och Alice Wallenbergs Stiftelse after the death of his brother Knut A. Wallenberg (1853-1938).
} 
3. Ax:son Johnson (Axel Ax:son Johnson, 1876-1958, his widow, his descendants and their spouses),

4. Klingspor (Carl Klingspor, 1847-1911, and his descendants and their spouses) and Stenbeck (Hugo Stenbeck, 1890-1977, his spouse and their descendants),

5. Mark (descendants to Knut J:son Mark, 1869-1958, and their spouses) and Carlander (descendants to Axel Carlander, 1869-1939, and their spouses),

6. Broström (descendants to Dan Broström, 1870-1925, and their spouses),

7. Bonnier (descendants to Karl-Otto Bonnier, 1856-1941, and their spouses),

8. Kockum (descendants to Frans Henrik Kockum, 1840-1910, and Carl Frans Henrik Kockum, 1878-1941, and their spouses),

9. Ericsson (Elof Ericsson, 1887-1961, his widow, his descendants and their spouses),

10. Åhlén (descendants to Johan Petter Åhlén, 1879-1939, and their spouses),

11. Kempe (descendants to Johan Carl Kempe, 1799-1872, and their spouses),

12. Söderberg (descendants to Olof Söderberg, 1872-1931, and their spouses),

13. Bergengren (descendants to Axel Bergengren, 1839-1901, and their spouses),

14. Edstrand (descendants to Hans Edstrand, 1855-1926, and their spouses).

Two spheres were management controlled, without the managers holding any controlling shares: Industrivärden-Handelsbanken and Custos/Säfveån-Skandinaviska Banken. Finally, the 'Dunker sphere' differed from the other spheres in the regard that it was controlled by Helsingsborg's city council and independent persons, after a donation from Henry Dunker (1870-1962).

The exercise of control was also investigated, and foundations were found to be the main controlling device in half of the ownership spheres. In particular, foundations were found to have been used to build and maintain a strong influence in the Swedish 
industry by small groups of high-impact entrepreneurs and their families. The controlling foundations were as follows (the foundations promote charitable purposes when nothing else is stated; founding year is in parentheses): ${ }^{42}$

- The Wallenberg family: The control primarily rests on Knut och Alice Wallenbergs Stiftelse (1917) and on the smaller Marianne och Marcus Wallenbergs Stiftelse (1963) and Stiftelsen Marcus och Amalia Wallenbergs Minnesfond (1960). There are also a number of minor foundations in the sphere: Jacob Wallenbergs Stiftelse, Särskilda fonden (1960), Stiftelsen för Rättsvetenskaplig Forskning (1947), Tekn. dr. Marcus Wallenbergs Stiftelse för utbildning $i$ internationellt industriellt företagande (1982), Berit Wallenbergs Stiftelse (1955), Marcus Wallenbergs Stiftelse för Internationellt Vetenskapligt Samarbete (1976), Ekon. dr Peter Wallenbergs Stiftelse för Ekonomi och Teknik (1996), Stiftelsen för Ekonomisk Historisk Forskning inom Bank och Företagande (1994) and Ekon. dr Peter Wallenberg Stiftelse för Entreprenörskap \& Affärsmannaskap (2016).

- The Industrivärden-Handelsbanken sphere: Svenska Handelsbankens Pensionsstiftelse (pension foundation), Svenska Handelsbankens Personalstiftelse (personnel foundation), Stiftelsen Oktogonen (personnel foundation $)^{43}$, Svenska Handelsbankens Pensionskassa (pension fund), Tore Browaldhs Stiftelse (1961) and Jan Wallanders och Tom Hedelius Stiftelse (1961). ${ }^{44}$ SCA och Essitys Personalstiftelser (personnel foundation) and SCA

\footnotetext{
${ }^{42}$ Foundations founded after the publication of the inquiry are included in the ownership spheres.

${ }^{43}$ A profit sharing foundation.

${ }^{44}$ Handelsbanken founded and financed Tore Browaldhs Stiftelse and Jan Wallanders och Tom Hedelius Stiftelse to honour their long-time commitment to the bank as CEOs and chairmen of
} 
och Essitys Pensionsstiftelser (pension foundation) are usually included in the sphere. ${ }^{45}$ All the foundations are controlled by management/employees.

- The Ax:son Johnson family: Axel och Margaret Ax: son Johnsons Stiftelse för allmännyttiga ändamål (1947). There is also a much smaller family foundation in terms of capital: Axel och Margaret Ax:son Johnsons Stiftelse (1947; family foundation). However, this foundation controls the majority of the investment company, Nordstjernan, which in turn controls the majority of the family's companies. $^{46}$

- The Dunker sphere: Henry och Gerda Dunkers Stiftelse (1953), Stiftelsen Henry och Gerdas Donationsfond Nr 1 (1962) and Stiftelsen Henry och Gerdas Donationsfond $\operatorname{Nr} 2$ (1962). ${ }^{47}$

- The Åhlén family: Åhléns-stiftelsen (1954).

- The Kempe family: Stiftelsen J.C. Kempes Minne (1936) and Stiftelsen Seth M. Kempes Minne (1941).

- The Söderberg family: Torsten Söderbergs Stiftelse (1960) and Ragnar Söderbergs Stiftelse (1960).

- The Ericsson family: ${ }^{48}$ Ollie och Elof Ericssons Stiftelse för Vetenskaplig Forskning (1958) and Ollie och Elof Ericssons Stiftelse för Välgörande Ändamål (1961).

the board. Hence, the foundations were not founded by Browaldh's, Wallander's or Hedelius' private wealth.

${ }^{45}$ SCA was a company controlled by the Industrivärden-Handelsbanken ownership sphere. In 2017, SCA was split into two companies, SCA and Essity.

${ }^{46}$ Helge Ax:son Johnsons Stiftelse (1941) is also identified to the group (Sundqvist, 19852015).

${ }^{47}$ Henry och Gerda Dunkers Stiftelse (1953). Stiftelsen Henry och Gerdas Donationsfond Nr 1 was administrated by Helsingborg's municipality (kommun), while Stiftelsen Henry och Gerdas Donationsfond Nr 2 and Henry och Gerda Dunkers Stiftelse were originally administrated by six independent persons (SOU 1968:7, p. 130).

${ }^{48}$ Note, it was not Lars Magnus Ericsson who founded L M Ericsson. 
The spheres Wehtje, Klingspor and Stenbeck, Mark and Carlander, Bergengren, Edstrand, Broström, Bonnier, Kockum and Custos/Säfveån-Skandinaviska Banken had no foundations, or their foundations were of minor importance for control. ${ }^{49}$

The capital transferred to the family-controlled foundations was chiefly shares in the family firm(s), which originated from entrepreneurs who were active during the Swedish industrialization in the mid-19 ${ }^{\text {th }}$ century. Knut Wallenberg (1853-1938), founder of Knut and Alice Wallenbergs Stiftelse, was the second-generation Wallenberg. His father, André Oscar Wallenberg (1816-1886), founded Stockholms Enskilda Bank in 1856, which is still under family control and has been critical for the Wallenberg group since its establishment. Axel och Margaret Ax:son Johnsons Stiftelse för allmännyttiga ändamål and Margaret Ax:son Johnsons Stiftelse were founded by Axel Ax:son Johnson (1876-1958), the second generation in the Ax:son Johnson family. In 1890, his father, Axel Johnson (1844-1910), founded the shipping company Nordstjernan, which later became an investment company and still is central for the control of the group. Henry Dunker's (1870-1962) father was one of the founders of Helsingborgs Gummifabrik AB in 1891. Henry Dunker developed the business successfully and was once estimated to be Sweden's richest person. He was co-founder of Trelleborgs Gummifabriks AB in 1905. Åhléns-stiftelsen was founded by the widow and children of Johan Petter Åhlén (1879-1939) in his memory. He was co-founder of Åhlén and Holm in 1899 (sole owner as from 1902), a mail-order company. Stiftelsen J.C. Kempes Minne and Stiftelsen Seth M. Kempes Minne was founded by Charlotte 'Lotty' Bruzelius (1855-1941) in memory of her father, Johan Carl Kempe, and her brother, Seth Michael Kempe. Johan Carl Kempe (1799-1892) was an entrepreneur

\footnotetext{
${ }^{49}$ For instance: Ingeborg och Knut J:son Marks Stiftelse (1917), Broströmska Stiftelsen (1924), Reinhold Edstrands och hans syskon Gunhild och Theklas Stiftelse (1951), Hugo Stenbecks Stiftelse (1962) and Sven och Dagmar Saléns Stiftelse (1968).
} 
whose business group became Mo och Domsjö AB after his death. Torsten Söderberg (1894-1960), founder of Torsten Söderbergs Stiftelse, and Ragnar Söderberg (19001974), founder of Ragnar Söderbergs Stiftelse, were grandsons of Per Olof Söderberg (1836-1881), founder of Söderberg \& Haak AB (1866). Elof Ericsson (1887-1961) was the chief executive officer and later chairman of the board for AB Åtvidabergs industrier $^{50}$ (founded in 1922). Elof Ericsson became a major shareholder in the late 1930s.

\section{Old and new family groups}

In 2018, there were approximately 17,000 foundations ${ }^{51}$ (County Administrative Board, Länsstyrelsen). It has been estimated that approximately 90 percent of all foundations are private (SOU 2009:65). The vast majority of foundations are small. ${ }^{52}$ Nevertheless, a few foundations control a large share of Swedish industry. Interestingly, the largest foundations are the same as those identified in SOU (1968:7). The foundations controlled by the Wallenberg and the Ax:son Johnson families stand out.

The Wallenberg foundations dominate and control or have a dominant influence over several of Sweden's most successful multinational firms. The Ax:son Johnson foundations also control or have a dominant influence on firms with substantial economic value. The Söderberg family controls Ratos, a listed investment company, via Torsten Söderbergs Stiftelse and Ragnar Söderbergs Stiftelse. The Dunker 'sphere' controls the listed company Trelleborg.

\footnotetext{
${ }^{50}$ Later FACIT, a world leading manufacturer of mechanical calculators.

${ }^{51}$ And an additional small number for personnel, pension and collective agreements foundations.

${ }^{52}$ We refer to the foundations controlled by the Wallenberg family as one foundation. We also include the holding company FAM AB, owned by Knut och Alice Wallenbergs Stiftelse, Marianne och Marcus Wallenbergs Stiftelse and Stiftelsen Marcus och Amalia Wallenbergs Minnesfond.
} 
Stiftelse Oktogonen and Svenska Handelsbankens Pensionsstiftelse are important shareholders in Handelsbanken. However, as of 2015, the IndustrivärdenHandelsbanken sphere is considered to be dissolved, as Fredrik Lundberg (1951-) has become a dominant owner in the former sphere companies. ${ }^{53}$

Fredrik Lundberg has successfully managed the heritage after his father, Lars Erik Lundbeg (1920-2001), the founder of the Lundberg family group. The Lundberg family is perhaps the most prominent of the new family groups that have emerged and is challenging the Wallenberg family for the most influence in the Swedish industry.

In addition to the Lundberg group, there are a few more emerging family groups that have created substantial wealth: the Gustaf Douglas (1938-) family, the Melker Schörling (1947-) family, the Persson family (founded by Erling Persson, 1917-2002, and now controlled by his son, Stefan Persson, 1947-) and the Olsson family (controlled by Dan Sten Olsson, 1947-, son of the founder Sten A. Olsson, 1916-2013). Notably, the new family groups use personal ownership for control and do not rely on foundations. ${ }^{54}$

\footnotetext{
${ }^{53}$ The other ownership spheres identified in SOU (1968:7) have disappeared or lost influence. The firms controlled by the Wehtje, Mark and Carlander, Bergengren, Edstrand, Broström, Kockum, Åhlén, Ericsson, and Kempe families were less successful, and these families are no longer regarded as ownership spheres. The Bonnier family has been and still is in publishing. Custos/Säfveån was dissolved by corporate activists in the 1980s. The Stenbeck and Klingspor group is the exception. The group has successfully transformed from investing in basic industry to investing in industries such as telecom and e-trade.

${ }^{54}$ The new family groups have also established foundations. Familjen Erling Perssons Stiftelse (founder of H\&M) was established in 1999, Lars Erik Lundbergs Stiftelse för forskning och utbildning founded in 1996, Lars Erik Lundbergs Stipendiestiftelse founded in 1991, Sten A. Olssons Stiftelse för Forskning och Kultur founded in 1996, Jane and Dan Olssons Stiftelse för Sociala Ändamål and Jane and Dan Olssons Stiftelse för Vetenskapliga Ändamål. These foundations are too small to be primarily used for control. The Kamprad family founded Familjen Kamprads Stiftelse (founder of IKEA) in 2011. The family has emigrated from Sweden, and IKEA is controlled by foundations domiciled outside Sweden.
} 


\section{Appendix C: The mixed case}

As described in the main text, one alternative way to illuminate how the tax system affects the return on investments made by private foundations is to decompose the return into dividends and price changes—or capital gains-based on the stock return on the public stock market and to use that as the basis for the analysis. The analysis based on this decomposition will show how private foundations would have been taxed if their stock return followed the average pattern on the stock market. The most influential private foundations have owned shares on the Swedish public stock market (see section 2.1 and Appendix B). Estimations made by Waldenström (2014) show that the share of dividend yield for the whole period (1870-2012) is, on average, approximately 40 percent.

The METR for private foundations can be recalculated given that 40 percent of the return of the investment project is received as dividends and the rest as capital gains. As the formal tax is 0 percent regardless of whether the income is received as dividends or capital gains, the ordinary METR calculation will not change. However, in line with the discussion in section 4.2 , if we include the negative cash flow implied by the requirement to give away the bulk of the net capital income, we can calculate a new METR given the above assumptions.

Figure $\mathrm{C} 1$ shows the METR given these assumptions. The METR fluctuates around 20-50 percent until World War II (ignoring the spikes). After the War and until the tax reform in 1990-1991, the METR fluctuates around 50-85 percent. After the tax reform, the METR decreases to approximately 40-50 percent. With these assumptions, the METR will be lower and not exceed 100 percent (ignoring the spikes during World War I), even if the negative cash flow from donating the bulk of the dividends to charitable purposes is included. 
If this METR is compared to the METR of an investment made by an owner of a listed company (representing a high-impact entrepreneur) where the return is divided in the same way, the result will mimic the result in the main text (see Figure C1). Personal ownership is favoured until World War I. During the interwar period, the results are mixed, and the METR is approximately the same. After World War II and until the 1990-1991 tax reform, particularly during the 1970s and 1980s, the tax system, including the donation requirement, favours control through private foundations, but this is not the case after the reform.

Figure $\mathrm{C} 1$. The marginal effective tax rate (METR) for private foundations and highimpact entrepreneurs, 1862-2018.

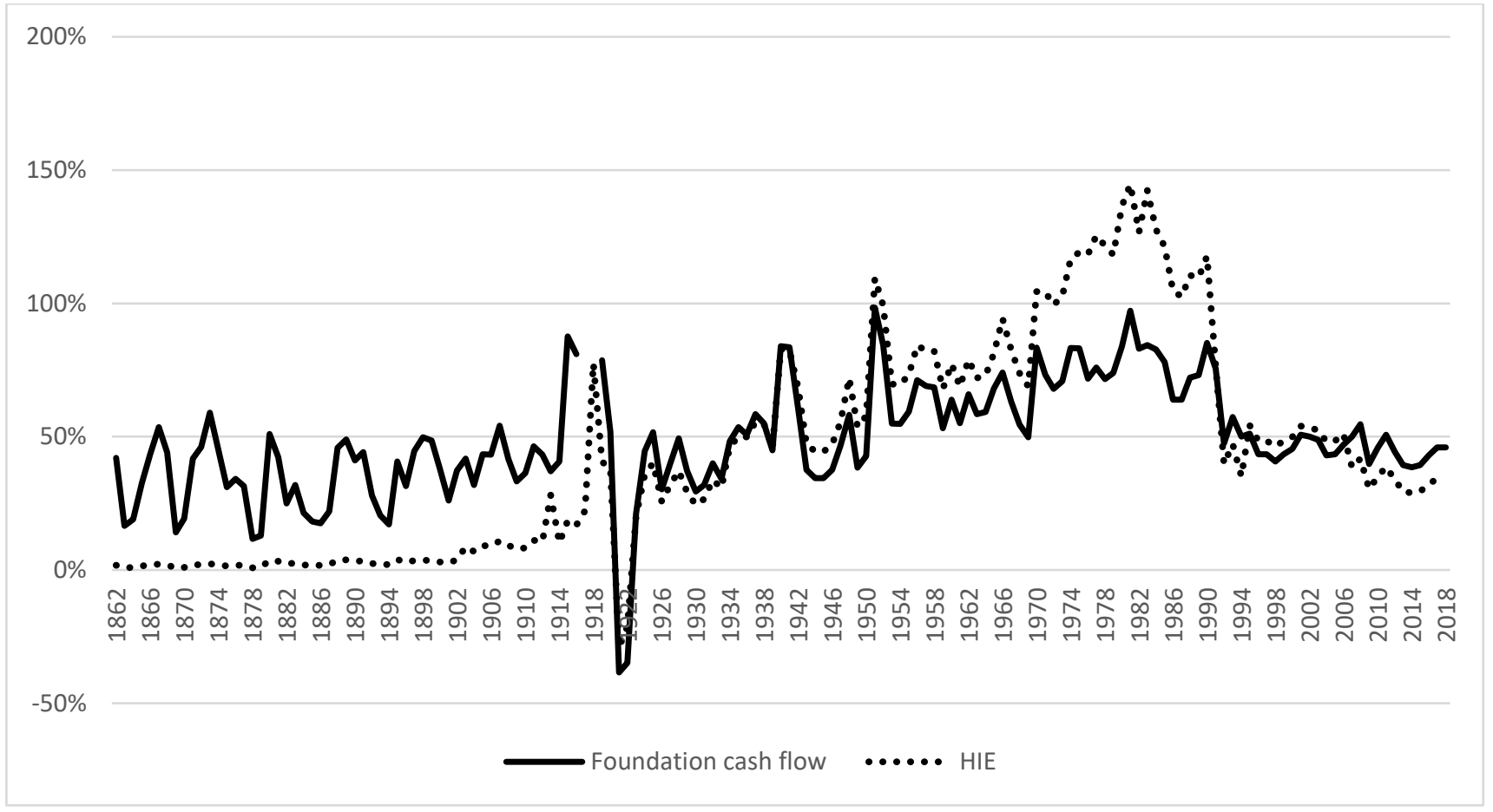

Note: Foundation cash flow considers the requirement that a private foundation has to donate the bulk of dividend income ( 80 percent is used in our calculations) to charitable purposes, which parallels the cash flow effect caused by dividend taxation. HIE refers to a high-impact entrepreneur who owns a listed firm and pays the top marginal tax rates. The calculations are made under the assumption that the stock return follows the average pattern of dividends and price changes (capital gains) on the stock market Source: Own calculations, Johansson et al. (2015) and updating. 